[Aus dem hygienischen Institut der Universität Halle-Wittenberg.]

(Director: Geh. Med.-Rath Prof. Dr. C. Fraenkel.)

\title{
Beitrag zur differential-diagnostischen Unterscheidung der Typhus- und typhusähnlichen Bakterien mit Hülfe der Agglutination.
}

Von

Dr. V. Porcile

aus Genus.

Die bakteriologische Typhusdiagnose hat im Laufe der letzten Jahre ausserordentlich bedeutsame Fortschritte gemacht. Mit der Verbesserung der Methoden ist freilich auch eine grössere Zahl verwandter typhusähnlicher Bakterienarten aufgefunden worden und damit in der speciellen Differencirung eine neue und nicht minder schwierige Aufgabe an uns herangetreten. Die hierfür zur Verfügung stehenden Untersuchungsmittel, soweit sie sich auf morphologische und culturelle Unterschiede der Bakterien stützen, gestatten in der Regel erst in ihrer Gesammtheit, nicht einzeln, ein Urtheil über den Charakter eines unbekannten Bakterienstammes. Man ist daher zur sicheren Identificirung auf die Heranziehung der serodiagnostischen Methoden angewiesen, welche sich für diesen Zweck in der That gut bewälren.

Bei seinen Versuchen mit dem Vibrio Cholerae asiaticae fand zuerst Pfeiffer(1) in der jetzt sog. Pfeiffer'schen Reaction ein ,biologisches“ Nittel, den Erreger der asiatischen Cholera von anderen ähnlichen Vibrionen zu unterscheiden.

Das Phänomen beruht bekanntlich darauf, dass das Blutserum von Thieren, die mit Choleraculturen vorbehandelt und so künstlich dagegen immunisirt sind, die Fähigkeit erlangt, Choleravibrionen innerhalb des lebenden Körpers unter Kügelchenbildung (.,Granula") allmählich zur 
Auflösung zu bringen. Der Process ist in der Bauchhöhle von Meerschweinchen jeder Zeit deutlich zu beobachten und kann in den einzelnen Stadien seines Verlaufes leicht controlirt werden, wenn man in gewissen Zwischenräumen Tröpfchen des peritonitischen Exsudats mittels Glascapillaren entnimmt und nun der Untersuchung im hängenden Tropfen unterwirft.

Dieses wichtige Ergebniss wurde sehr bald von vielen Seiten bestätigt. Es sei nur auf die Arbeiten von Metschnikoff, Bordet, Dunbar, Sobernheim, Gruber u. A. hingewiesen.

Pfeiffer dehnte nachher seine Versuche gemeinsam mit Kolle (2) auf Typhusbacillen aus, wobei er zu demselben Hauptergebniss gelangt ist.

Eine höchst werthvolle Ergänzung der durch die Pfeiffer'sche Reaction dargestellten Eigenschaften des specifischen Serums wurde in der auss erhalb des Thierkörpers im Reagensglase ausführbaren Agglutination gefunden. Schon früher hatte man ron verschiedenen Seiten (Metschnikoff, Bordet, Pfeiffer) auf eigenartige Veränderungen und entwickelungshemmende Einwirkungen aufmerksam gemacht, welche das Immunserum auf die zugehörige Bakterienart auch in vitro auszuüben pflegt, doch war es erst Gruber (3), der diesem Vorgang auf Grund seiner in Gemeinschaft mit Durham und Herbert ausgeführten Untersuchungen eine ganz besondere Bedeutung zuerkannte. Auch hier handelte es sich, wie namentlich die weiteren Untersuchungen von Pfeiffer und Kolle (2) bestätigten, um streng specifische Wirkungen, insofern als ein Choleraserum oder Typhusserum immer nur echte Cholera- bezw. Typhusbakterien beeinflusste, ,agglutinirte".

So bekam man in dieser Gruber'schen Reaction ein neues treffliches Hülfsmittel in die Hand, Typhusbakterien vermöge der agglutinirenden Fähigkeiten des Typhusserums im Reagensg lase zu identificiren, ähnlich wie Pfeiffer die baktericiden oder bakteriolytischen Eigenschaften des Immunserums zur Identificirung der Bakterien innerhalb des Thierkörpers benutzte. Bezŭglich der Differentialdiagnose von Typhus- und Colibakterien, sowie anderen āhnlichen Mikroorganismen dieser Gruppe nimmt die Agglutinationsprüfung heutzutage eine bevorzugte, ja eigentlich die erste Stelle ein. Freilich liegen die Verhältnisse hier anscheinend nicht ganz so einfach und eindeutig, als es nach den ersten einschlägigen Beobachtungen wohl zu vermuthen war.

Man gelangte nämlich im weiteren Verlaufe der Forschung zu Ergebnissen, welche mit den Anschauungen streng specifischer Wechselbeziehungen zwischen Immunserum und der homologen Bakterienart in gewissem Widerspruch standen und daher zunächst den differentialdiagnostischen Werth der Agglutinationsprobe zu beeinträchtigen geeignet 
waren. Man fand insbesondere, dass in manchen Fällen das Immunserum auch auf fremde Bakterienarten einen nicht unerheblichen Einfluss ausübte, dass ein Typhusserum also z. B. ausser echten Typhusbakterien einzelne typhusähnliche Stämme mehr oder minder deutlich agglutinirte und sprach von "Gruppenreaction", „Mitagglutination" u. s. w. Ich beziehe mich hier besonders auf die "Arbeiten von Van de Velde (5), Stern (6), Mann (7), Jatta (8), Sternberg (9), Rothberger (10), Radziewsky (11), Castellani (12) u. A.

Als dann in den Jahren 1900 und 1901 Schottmüller (13) bei einer Reihe von Krankheitsfällen in seinen "Paratyphusbacillen" typhusähnliche Stäbchen fand, die offenbar die gleichen klinischen Erscheinungen hervorzurufen vermochten, wie echte Typhusbacillen, sich von den letzteren aber sicher nach ihrem culturellen Verhalten unterscheiden liessen, war die Frage nach der Bedeutung und dem Charakter der typhusähnlichen Bakterienarten, vor Allem nach deren Beziehungen zu den Typhusund Colibakterien in ein neues Stadium von grosser wissenschaftlicher und praktischer Bedeutung getreten, und damit naturgemäss auch der Agglutination eine ganz besonders schwierige und wichtige Aufgabe gestellt.

Die Schottmüller'schen Bakterien repräsentirten zwei verschiedene Typen, die als Paratyphus A und B benannt zu werden pflegen.

Bald nach Schottmüller beschrieb Kurth (14) in dem Bacillus bremensis febris gastricae einen als eine besondere Art abzugrenzenden typhusähnlichen Mikroorganismus. Brion und Ka'yser (15) gelang es in Strassburg einen Bacillus zu isoliren, den sie dem einen Typus Schottmüller's, dem Typus A, einreihten; nach ihren Untersuchungen konnten sie ausserdem den Kurth'schen Bacillus mit dem Typus B identificiren. Kurz nachher beschrieb Kayser (16), ebenfalls in Strassburg, noch 3 Fälle, die man seiner Meinung nach als Paratyphus B betrachten sollte.

Auch der von Hünermann zuerst in Saarbrücken gefundene und dann von Conradi, Drigalski und Jürgens (17) gemeinsam untersuchte Bacillus wurde in die Gruppe des Paratyphus B eingerechnet.

Diese nen entreckten und als Paratyphus bezeichneten Bacillen hatten, ausser besonderen culturellen Merkmalen, die gemeinsame Eigenschaft, dass sie von Typhusseris gar nicht, oder wenigstens nicht in bedeutender Weise agglutinirt, dagegen von homologen Seris vollkommen und in höherem Grade beeinflusst wurden. Die Unterscheidung der Paratyphusbacillen in 2 Typen hat ihren Grund in gewissen culturellen Differenzen und in dem verschiedenen Verhalten gegenüber der Agglutination.

Einer genaueren vergleichenden Agglutinationsprüfung unterwarfen Bruns und Kayser (18) die eben erwähnten typhusähnlichen Bakterien- 
stämme, indem sie zugleich echte Typhusbacillen und verschiedene Colibakterien zur Prüfung heranzogen und nun die agglutinirende Wirkung der Immunsera genau quantitativ zu ermitteln suchten. Bei ibren Untersuchungen kamen sie zu folgendem Ergebniss: Verschiedene Typhusbacillen werden von verschiedenen Typhusseris fast gleich stark agglutinirt. Den Paratyphusbacillen gegenüber aber besitzen lediglich sehr starke Typhussera Agglutinationskraft, schwächere hingegen äussern keinen derartigen Einfluss. Im Uebrigen sind die Sera des Paratyphus A und B streng specifisch, so dass also die ersten nur Bacillen des Typus A, die letzten nur Bacillen des Typus B agglutiniren. Von Coliseren werden Typhusbacillen selten und sehr schwach, Paratyphusbacillen beider Gruppen nicht agglutinirt. Was die Colibacillen betrifft, so sind sie den Paratyphusseren gegenüber unempfindlich, werden aber durch sehr starke Typhussera manchmal in gewissem Grade beeinflusst. Colisera wirken auf einige Coliarten ziemlich stark, auf andere gar nicht.

Durch die Beobachtungen von Jürgens (19), die sich wesentlich auf die Eigenschaften des menschlichen Serums bei Typhus- und Paratyphuserkrankungen beziehen, wurde festgestellt, dass in der Regel eine nicht unerhebliche Mitagglutination der fremden Bakterienart stattfindet.

Zupnick und Posner (20) prüften die Agglutinationsverhältnisse des Serums bei zahlreichen Typhusfällen, einigen Paratyphusfällen und anderen Krankheiten. Sie fanden, dass Sera von Typhuskranken auch die Paratyphusbacillen, sowie dass Sera von Paratyphuskranken auch Typhusbacillen agglutinirten: der Agglutinationstiter war aber den homologen Stämmen gegenüber am höchsten. Die Verfasser konnten auch zwei Paratyphusarten, entsprechend $A$ und $B$, unterscheiden.

Korte (21) isolirte aus einem typhusverdächtigen Falle einen Bacillus, der von dem Serum des betreffenden Patienten agglutinirt wurde, und zwar ganz in der nämlichen Weise, wie die zum Vergleich herangezogenen Paratyphusbacillen des Typus B und der Kurth'sche Bacillus. Dagegen wirkte das Serum auf Typhus-, Paratyphus A-, Colistämme und Bact. enteritidis (Gärtner) nur bei Anwendung stärkerer Concentrationsgrade. Ein gleiches Resultat gab ein von Kaninchen mit dem isolirten Bacillus gewonnenes Immunserum. Noch in einem zweiten Falle wurden ähnliche Verhältnisse ermittelt. Weitere besondere Cntersuchungen über die Agglutination ron Paratyphusbacillen durch Typhusserum ergaben, dass es Sera giebt, welche

I. Paratyphusbacillen nicht mitagglutiniren,

II. nur den Paratyphusbacillus A mitagglutiniren,

III. beide Typen von Paratyphusbacillen agglutiniren. 
Die Agglutination der Paratyphusbacillen blieb aber in jedem Falle hinter derjenigen der wahren Typhusbacillen zurück.

Hoffmann (22) erhielt bei der Untersuchung der Immunsera von Typhus-, Coli- und typhusähnlichen Bacterien durchaus specifische Agglutinationswirkungen.

Lipschütz (23) prüfte eine Reihe verschiedener Typhusimmunsera und fand hierbei eine ausgesprochene specifische Wirkung, insofern, als die typhusähnlichen Stämme meist zwar mitagglutinirt wurden, zum Theil sogar bis 1:200-400, niemals aber auch nur annähernd in dem Maasse, wie echte Typhusbacillen. Der Titer des Serums für diese letzteren betrug gewöhnlich 1:10000 bis 1:20000. Lipsehütz räth daher, entsprechend dem Vorschlage Wassermann's, möglichst hochwerthige Sera bezw. sog. „Endverdünnungen" zur Bestimmung verdächtiger Culturen zu benutzen.

Fälle von Paratyphus wurden alsdann von Erne (24) und Blumenthal (25) beschrieben.

Auf Grund vergleichender Untersuchungen, bei denen auch die Agglutinationsprüfung zur Differentialdiagnose herangezogen wurde, kommt Bonh off (26) zu dem Schlusse, dass der Paratyphusbacillus B, der Bacillus enteritidis Gärtner und der Löffler'sche Mäusetyphusbacillus weder durch die biologischen noch durch die Agglutinations- oder bakteriolytischen Untersuchungsmethoden $\mathrm{zu}$ trennen seien und nur in ihren pathogenen Eigenschaften gewisse Unterschiede aufweisen.

Vor Kurzem haben Ballner und v. Sagasser (27) nochmals die Frage der Specifität der Agglutination zum Gegenstand experimenteller Untersuchungen gemacht. Auf Grund ihrer Befunde halten sie sich nicht für berechtigt, eine absolute Specifität anzuerkennen, obwohl in allen Fällen die Agglutinationswirkung des Serums der eigenen Art gegenüber bedeutend stärker zu Tage trat als gegen die fremden Species.

Wie aus den oben angeführten Arbeiten hervorgeht, ist die Frage der Specifität der Sera im Gebiete der Typhus-, Coli- und Paratyphusbacillen noch nicht als völlig geklärt zu betrachten. In manchen Beziehungen herrsehen sogar nicht unbedeutende Meinungsverschiedenheiten.

Ausserdem sind einige typhusähnliche Bacillen, wie z. B. der Bacillus enteritidis Gärtner's, der Bacillus faecalis alcaligenes u. a., von manchen Autoren gar nicht, von anderen nur nebensächlich in Betracht gezogen.

Es war deshalb der Mühe werth, nicht nur aus wissenschaftlichen, sondern auch aus praktischen Gründen, alle diese verschiedenen Bakterien nochmals bezüglich ihrer Agglutinationsfähigkeit in einer möglichst vollkommenen Versuchsreihe zu prüfen.

Auf Anrathen des Herrn Prof. Dr. Sobernheim unternahm ich es, Untersuchungen hierüber anzustellen. 
Die Stämme, welche mir zur Verfügung standen, waren folgende:

\begin{tabular}{|c|c|c|}
\hline \multirow{2}{*}{\multicolumn{3}{|c|}{ Typhus „Gelsenkirchen“" }} \\
\hline Typhus , & & Bacillus enteritidis Gärtner \\
\hline$"$ & „Friedrichshain" & $\begin{array}{l}\text { Baclilus enteritidis Gártner } \\
\text { Bacillns dysenterine (Kruse) }\end{array}$ \\
\hline$"$ & „Galle“" & \\
\hline , & „Eiter“ & Bacillus faecalis alcaligenes \\
\hline$"$ & „Roseola“" & \\
\hline$"$ & D. & B. „Nietleben“" \\
\hline,$\quad x$ & $\mathrm{X}$ & B. coli I \\
\hline Paratyphus & is Strassburg A & B. coli II \\
\hline$"$ & Strassburg B & B. coli III \\
\hline$\eta$ & Schottmūller A & B. coli IV \\
\hline " & Schottmüller B & \\
\hline$"$ & Saarbrücken & \\
\hline
\end{tabular}

Von diesen Stämmen wurden die meisten der Sammlung des hygienischen Instituts entuommen, andere aus Krankenmaterial frisch gezüchtet (T. „Eiter", „Roseola“, D und X, B. coli III und IV), wieder andere endlich in liebenswürdiger Weise von Hrn. Prof. Dr. Kolle dem Institut überlassen (Paratyphusbacillen).

Die Herkunft der Typhusculturen ergiebt sich aus ihren besonderen Bezeichnungen. Stamm D. ist aus Urin, Stamm $\mathbf{X}$ aus dem Stuhle eines Typhuskranken gezüchtet worden. Die verschiedenen Colistämme waren ausnahmslos aus normalen bezw. typhusverdächtigen Stuhlproben entnommen worden.

Auf eine ausführliche Beschreibung der morphologischen und culturellen Merkmale unserer Culturen möchte ich rerzichten und nur ganz allgemein so viel bemerken, dass eine diesbezügliche Prüfung der einzelnen Stämme deren völlig typisches und bekanntes Verhalten ergeben hat. Ich erwähne besonders, dass die untersuchten Paratyphusbacillen sich von den echten Typhusbacillen wesentlich dadurch unterscheiden, dass sie Traubenzucker vergähren und Neutralrothagar zum Fluoresciren bringen, andererseits gegenüber den Colibacillen durch den Nangel der Milchgerinnung und durch blaues Wachsthum auf Drigalski-Agar charakterisirt sind. Die zum Typus A gehörigen Stämme differenziren sich ausserdem von denen des Typus B dadurch, dass letztere die Fähigkeit besitzen, Nilch nach mehreren Wochen aufzuhellen und Lakmusmolke nach einigen Tagen alkalisch (blau-violett) zu machen. Der als Bac. Nietleben bezeichnete Mikroorganismus entstammte einer verdächtigen Stuhlprobe und charakterisirte sich morphologisch sowohl wie durch zarte bläuliche Colonieformen auf dem Drigalski'schen Nährboden, fehlende Nilchgerinnung, Gasbildung in traubenzuckerhaltigen Näbrböden u. s. w. als eine den 
Paratyphusbakterien nahestehende Art. Nur unterschied er sich culturell von diesen letzteren durch die dem Bac. coli fast gleichkommende Fähigkeit, den Barsiekow'schen Milchzuckernährboden zu zersetzen und zu verfärben.

Zur Gewinnung der Immunsera dienten Kaninchen im Gewicht von 1600 bis $2500 \mathrm{grm}$. Die Thiere erhielten in der Regel eine einmalige intravenöse Injection abgetödteter Cultur, derart, dass 2 Oesen einer ca. 20 stündigen Agarcultur in $2^{\mathrm{ccm}}$ physiologischer Kochsalzlösung aufgeschwemmt, $1 / 2$ Stunde im Wasserbade auf $65^{\circ}$ erhitzt und nun den Kaninchen in die Ohrvene eingespritzt wurden. Die Blutentnahme erfolgte alsdann nach 8 bis 10 Tagen und lieferte bei den Typhusstämmen ausnahmslos, weniger sicher bei den anderen Bakterienarten, bereits ein hochwerthiges und für unsere Prüfungszwecke brauchbares Serum. In denjenigen Fällen, in denen die einmalige Culturinjection noch nicht zum Ziele geführt hatte, wurden weitere Impfungen mit steigenden Dosen, theilweise auch mit lebenden Culturen vorgenommen.

Die agglutinirende Eigenschaft der Sera-wurde von mir im Allgemeinen makroskopisch geprüft; sehr oft aber auch, besonders um in zweifelhaften Fällen die Grenze sicher festzustellen, nahm ich die mikroskopische Methode zu Hülfe. Die Ausführung schloss sich den von Kolle gegebenen Vorschriften auf das Engste an und geschah in folgender Weise: Von dem zu prüfenden Serum wurden mit physiologischer Kochsalzlösung Verdünnungen von $1: 20$ bis $1: 10000$, in manchen Fällen auch bis $1: 20000$ angefertigt. Von jeder Verdünnung füllte ich $1^{\mathrm{ccm}}$ in Reagensgläser von gewöhnlicher Grösse, und verrieb darin je eine Oese der betreffenden, 20 Stunden alten Agarcultur. Nach 1-, 3., 6- und 24 stündigem Aufenthalt im Brütschrank bei $37^{\circ}$ wurden die Röhrchen besichtigt. Die endgültige und entscheidende Controle erfolgte aus Gründen, die später noch eingehender erörtert werden sollen, erst nach 20 bis 24 Stunden.

Hiermit habe ich die allgemeinen Züge des von mir angewendeten Verfahrens kurz geschildert. Bevor ich aber auf nähere Angaben meiner Versuche eingehe, sei es mir erlaubt, einige Besonderheiten zu erwähnen, welche ich im Laufe der Untersuchungen beobachten konnte. Eine Erfahrung bezieht sich, wie bereits oben angedeutet wurde, auf die Gewinnung des Serums.

Die Herstellung eines wirksamen Serums ist nicht in jedem Falle, d. h. mit jedem Stamme gleich leicht, und zwar liegt die Schwierigkeit oft schon darin, dass die betreffende Cultur, selbst in sehr geringer Dosis eingespritzt, das Thier tödtet.

Der Stamm Kruse tödtete z. B. die Thiere schon in der Menge 
von $1 / 10,1 / 25$ Oese abgetödteter Cultur. ${ }^{1}$ Ein kräftiges Kaninchen von 4500 grm Körpergewicht, dem ich $1 / 3$ Oese eingespritzt hatte, blieb $3^{1} / 2$ Tage am Leben. Ebenso lange konnte ish ein anderes Kaninchen von 2500 grm Gewicht, das ich mit $1 / 8$ Oese geimpft hatte, durch wiederholte NaCl-Lösung-Injection am Leben erhalten, doch erwies sich das von diesen Thieren gewonnene Serum als völlig wirkungslos. Auch bei der Impfung mit den Stämmen Saarbrücken, Strassburg und Schottmüller zeigte sich, dass nur wenige Thiere eine Injection von 2 Oesen der betreffenden Cultur auf einmal ertragen konnten, dass dagegen nach Injection ron geringeren Mengen, auch nach mehrmaliger Wiederholung. noch kein wirksames Serum erzielt wurde. Andere Stämme wiederum wurden zwar in sehr grossen Mengen ertragen, ohne dass aber auch hier das Thier nun ein wirksames Serum lieferte. Das ist z. B. der Fall gewesen bei zwei Colistämmen: B. coli III und B. coli IV. Mit B. coli IV wurden zwei Kaninchen wiederholt geimpft, bis zur Einspritzung von 10 Oesen auf einmal, ein drittes bekam fast ebenso grosse Mengen des B. coli III, trotzdem zeigten die Sera gar keine oder nur ein sehr schwaches Agglutinationsvermögen. Selbst die Einspritzung von 1 und 2 Oesen lebender Cultur konnte dem Serum keine stärkeren agglutinirenden Eigenschaften verleihen.

Ich betone hier nochmals, dass ich mich immer und allein der intravenösen Injection bedient habe.

Die einmalige intravenöse Injection einer Dosis von 2 Oesen erwies sich als Optimum lediglich bei allen Typhusstämmen. Hierzu können auch Bact. Nietleben und B. faecalis alcaligenes gerechnet werden. Eine hōhere Menge brachte bei diesen Culturen bemerkenswerther Weise nicht immer eine Steigerung des Agglutinationstiters des Serums hervor; eine niedrigere (1 Oese) dagegen leistete weniger Gutes.

Die Einspritzung einer Oese lebender Cultur übte keinen nennenswerthen Einfluss auf das Agglutinationsvermögen des Blutserums eines schon mit abgetödteten Culturen vorbehandelten Thieres aus.

Was nun die bei meinen Agglutinationsprüfungen gemachten allgemeinen Erfahrungen anlangt, so war es für mich von besonderem Interesse, die Leistungsfähigkeit der makroskopischen uud mikroskopischen Methode zum Gegenstand vergleichender Untersuchungen zu machen.

Nach den zahlreichen wiederholten Prüfungen, die ich nach dieser Richtung angestellt habe, fühle ich mich zu der Angabe berechtigt, dass man mit der makroskopischen Betrachtung, wobei nöthigenfalls eine Lupe zu Hülfe genommen werden kann, im Stande

\footnotetext{
${ }^{1} \mathrm{Vgl}$. Lentz, Handbuch von Kolle und Wassermann. Bd. II.
} 
ist, den positiven oder negativen Ausfall der Agglutination ebenso gut.wie mit der mikroskopischen Probe zu beurtheilen. Natürlich kommen hier auch gewisse Schwierigkeiten vor. Vor Allem muss man darauf achten und daran fest halten, dass das sicherste Criterium eines positiven Ausfalles der Agglutination in der Anwesenheit zahlreicher feiner, in der Flüssigkeit gleichmässig vertheilter Körnchen von gleicher Grösse besteht. Hat sich in einem Röhrchen ein Bodensatz mit darüber stehender klarer Flüssigkeit gebildet, so ist daraus noch kein sicherer Sehluss auf einen positiven Ausfall zu ziehen. Das Röhrchen muss zuerst geschüttelt, möglichst sehräg und nach oben gehalten und so bei dem von der Zimmerdecke reflectirten, durchfallenden Lichte betrachtet werden. (Vgl. Kolle.) Hat keine Agglutination stattgefunden, so löst sich der Bodensatz wieder zu einer gleichmässig trüben Flüssigkeit auf, ohne Andeutung von Körnchenbildung, bei einem positiven Ausfall hingegen hat man jenes oben geschilderte Bild vor sich. Je nach der Intensität der Reaction können die Körnchen mehr oder weniger zahlreich sein: der sicher beweisende Charakter ist nur in ihrer gleichen Grösse und gleichmässigen Vertbeilung zu suchen. Das findet sich immer, gleichgültig ob man eine starke Concentration, etwa $1: 20$, oder eine weitgehende Verdünnung $(1: 2000$ bis $1: 10000)$ eines hochwerthigen Serums vor sich hat. In dem ersten Falle erscheinen wegen der Stärke der Agglutination die Granula bei den ersten Schüttelbewegungen zwar viel grösser, schüttelt man aber weiter und stärker, so werden auch hierbei die grossen Granula zu feinsten Körnchen zertheilt. Lediglich die Zahl dieser Körnchen ist in den stärkeren Serumconcentrationen eine grössere.

Alle jene Fälle, in denen ein flockiger oder selbst körniger Bodensatz beim Schütteln vollständig verschwindet und sich unter gleichmässiger Trübung in der Flüssigkeit vertheilt, habe ich bei meinen Aufzeichnungen stets als "negativ" vermerkt. Hat man auch von mancher Seite vorgeschlagen, im Gegensatz zur echten Agglutination eine „Pseudoagglutination" dann anzunehmen, wenn die in der Flüssigkeit auftretenden Körnchen beim Aufschütteln sich zertheilen und verschwinden, so habe ich diese Bezeichnung lieber für einen anderen Vorgang reservirt. Es lrommen nämlich Fälle vor, wobei in einer sonst gleichmässig trüben Flüssigkeit mehr oder weniger zahlreiche Granula erscheinen, welche von verschiedener Grösse sind, zuweilen sich wie Häutchen oder unregelmässige Bröckelchen von verschiedenem Aussehen darstellen, durch Schütteln zwar in kleinere Elemente zertheilt, nie aber zu gleich grossen Körnchen und zu einer gleichmässigen Vertheilung gebracht werden können. Andererseits gelingt es auch nicht, sie durch Schütteln zum Verschwinden zu bringen. Ein geübtes Auge lraun ohne Schwierigkeit die zwischen den 
ziemlich weit von einander entfernten . Granulis befindlichen Partieen homogen getrübter Flüssigkeit wahrnehmen; bei Anwendung einer Lupe wird die Erscheinung noch klarer. Betrachten wir einen Tropfen der geschüttelten Flüssigkeit unter dem Mikroskop, so finden wir ausser einigen grossen Haufen, die den makroskopisch sichtbaren Krümeln entsprechen, kein Zeichen einer stattgehabten Agglutination: jede Spur einer weiteren Häufchenbildung fehlt rollständig, und alle übrigen Bacillen sind vereinzelt und, je nach der Art der Cultur, beweglich zu sehen. Die Entstehung eines solchen Bildes beruht zuweilen auf der Beschaffenheit der Cultur, die sich trotz aller erdenklichen Sorgfalt und Vorsicht sehr schwer zerreiben lässt, meist aber stellt sich diese „Pseudoagglutination“ erst nachträglich bei einer anfänglich völlig homogenen Bakterienaufschwemmung ein. Welchem Umstande diese Erscheinung im letzteren Falle zuzuschreiben ist, bin ich nicht im Stande zu sagen. Gegen eine wahre Agglutination spricht das geschilderte makroskopische und mikroskopische Verhalten; ausserdem die Thatsache, dass es sich um kein constantes Vorkommniss bei einer und derselben Cultur einem und demselben Serum gegenüber handelt, und das scheinbar regellose und gewissermaassen willkürliche Auftreten bei irgend einer Verdünnung, während rerschiedene andere höhere oder niedrigere Verdünnungen k'eine Andeutung ron Agglutination wahrnehmen lassen.

Diese letztere Erscheinung ist freilich, wie ausdrücklich herrorgehoben sei, keine absolut regelmässige und bei dem Phänomen der Pseudoagglutination etwa ausnahmslos zu beobachtende, rielmehr kann auch gelegentlich die Scala der Serumverdünnungen bis zu einer bestimmten Grenze eine continuirliche Einwirkung auf die Bakterien erkennen lassen. In diesem Falle stellen aber die übrigen Charakteristika der Pseudoagglutination das Wesen des Vorganges über jeden Zweifel sicher. Nicht selten findet man auch hierbei das Controlröhrchen anscheinend ,agglutinirt".

Ich hielt eine eingehende Erörterung dieser Frage für nothwendig, um ror etwaigen Täuschungen bei der makroskopischen Agglutination zu warnen.

Noch ein Wort über die besondere Art und Weise der Probe auf Agglutination. Entsprechend dem neverdings wohl ziemlich allgemein geübten Verfahren habe ich die Untersuchung im hängenden Tropfen stets bei schwacher Vergrösserung oder höchstens mit starkem Trockensystem (Oc. 3, Obj. 8) vorgenommen, und hierbei durchaus eindeutige Ergebnisse erhalten. Die Anwendung schwacher Objective bietet im Besonderen ausser der grösseren Schnelligkẹit und Bequemlichkeit der Ausführung den Vortheil, dass der Tropfen in seiner ganzen Breite und Tiefe durchmustert werden 
kann. Bei der Untersuchung mit der Oelimmersion können unbeweglich gewordene und agglutinirte Bacillen durch ihr Sinken nach unten dem Auge entgehen, ferner können bei dem kleineren Gesichtsfeld der Oelimmersion einige gerade dem Auge sich zeigende Häufchen ein falsches Urtheil über die Stärke der Agglutination entstehen lassen.

Um nun auf die Resultate meiner Agglutinationsprüfungen im Einzelnen genauer einzugehen, möchte ich im Folgenden zunächst einige Versuchsreihen bringen, welche die Agglutination verschiedener Typhussera gegenüber den einzelnen Typhusstämmen betreffen. Die aufgezeichneten Ergebnisse beziehen sich stets auf die nach 20 bis 24 Stunden vorgenommene Besichtigung, da man, wie mich wiederholte vergleichende Prüfungen gelehrt haben, erst nach dieser Zeit die Resultate als endgültig zu betrachten berechtigt ist. In einer besonders zu diesem Zweeke beigefügten späteren Tabelle (Tab. VIII) wird dies klar und deutlich veranschaulicht.

\section{Agglutinirende Wirkung der Typhussera gegenüber Typhusstämmen. ${ }^{1}$}

Tabelle I. Serum Gelsenkirchen.

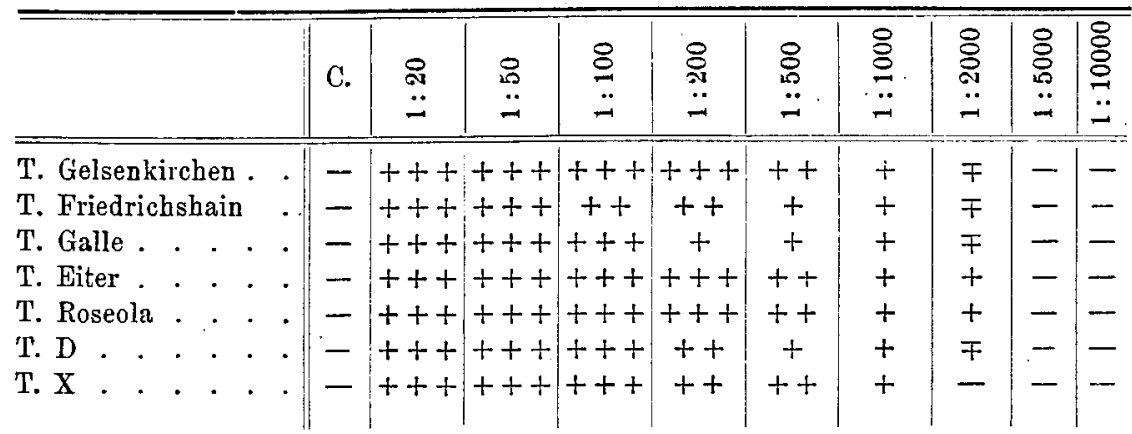

Tabelle II. Serum Friedrichshain.

I. Gelsenkirchen. . $\|-1+++1+++++1+++1+++1++1++1+1 \mp$ T. Friedrichshain . . $-++++++++++++++++++++1++$

T. Galle. . . . -+++++++++++++++++++

T. Eiter. . . . $-1+++++++++++1+$

T. Roseola . . . $-++++++++++++++1+1+$

T. D... . . . $-1+++++++++++1++$

T. X. . . . . I $-1++++++1+++1+++1+1+1-1-$

1 Das Ergebniss ist bei positivem Ausfalle der Agglutination je nach der Stärke durch 1 bis 3 Kreuze $(+,++,+++)$, bei negativem Ausfall durch ,.-“ Zeichen vermerkt. Das ₹ Zeichen bedeutet eine schwache, aber eben noch erkennbare Wirkung. Ps bedeutet „Pseudoagglutination“. C. bezeichnet das Controlröhrchen. 
Tabelle III. Serum Galle.

\begin{tabular}{|c|c|c|c|c|c|c|c|c|c|c|}
\hline & C. & $\stackrel{\circ}{\stackrel{\circ}{ت}}$ & 足 & $\begin{array}{l}8 \\
0 \\
\ddot{\pi} \\
\end{array}$ & 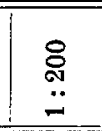 & $\begin{array}{r}8 \\
: \\
: \\
-1\end{array}$ & $\begin{array}{l}\text { О } \\
0 \\
\ddot{0} \\
\end{array}$ & $\begin{array}{l}\stackrel{8}{\circ} \\
\stackrel{-}{*} \\
\end{array}$ & $\begin{array}{l}\overline{8} \\
0 \\
\dddot{0} \\
-1\end{array}$ & $\begin{array}{l}\text { § } \\
\stackrel{0}{-}\end{array}$ \\
\hline $\begin{array}{l}\text { Gelsenk } \\
\text { Friedri }\end{array}$ & - & & & $\begin{array}{l}+++ \\
+++\end{array}$ & $\begin{array}{l}+++ \\
+++\end{array}$ & $\begin{array}{c}t+ \\
t++\end{array}$ & $\begin{array}{l}++ \\
++\end{array}$ & + & - & - \\
\hline Gall & - & +++ & ++ & ++ & ++ & ++ & + & + & + & - \\
\hline & - & +++ & ++ & ++ & ++ & + & + & + & - & - \\
\hline Roseola & - & +++ & $++t$ & ++ & ++ & $+t$ & ++ & + & -- & - \\
\hline $\mathrm{D} \cdot \cdot$ & - & $t+t$ & +++ & $\begin{array}{l}++ \\
++\end{array}$ & ++ & ++ & + & + & 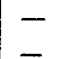 & \\
\hline
\end{tabular}

Tabelle IV. Serum Eiter.

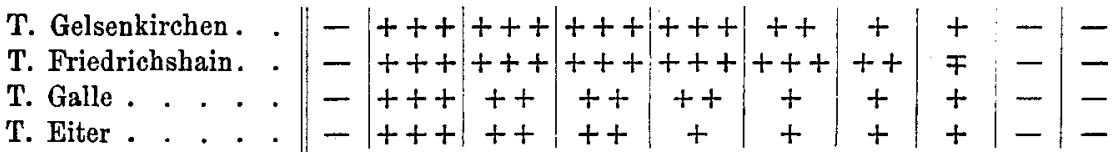
T. Eiter. . . .
T. Roseola . . .

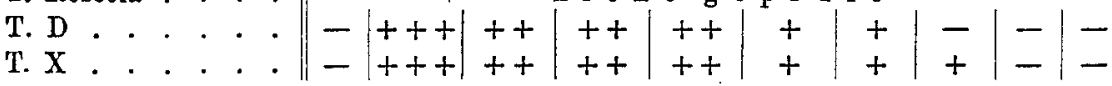

Tabelle V. Serum Roseola.

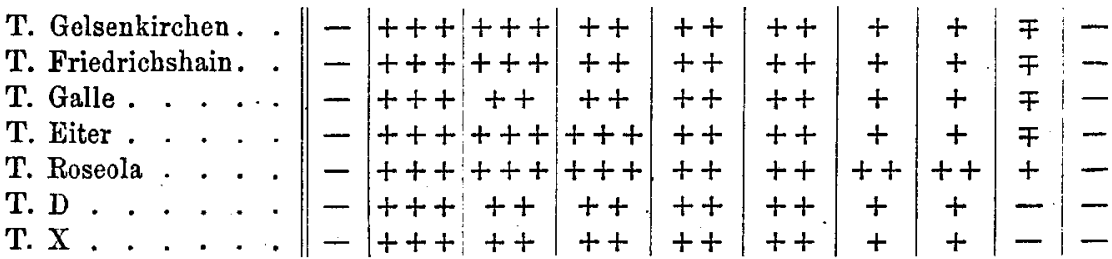

Tabelle VI. Serum D.

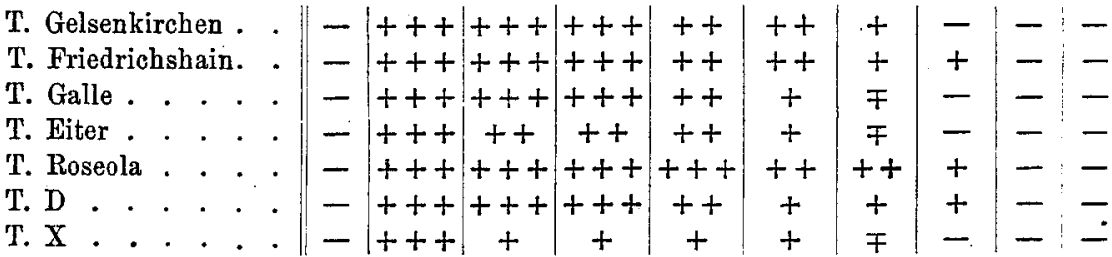

Tabelie VII. Serum $X$.

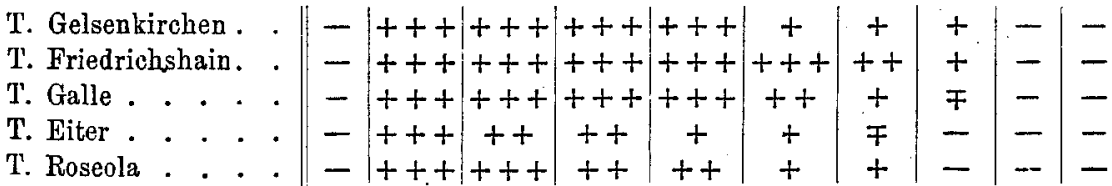
T. D..... n i c ht gepr a

T. X.... . I- $1+++1+++1++1++1+1+1 \neq 1-1-$ 
Aus diesen Tabellen geht deutlich hervor, dass die von mir untersuchten verschiedenen Typhusculturen von den verschiedenen Typhusseris durchweg fast genau in denselben Grenzen und in gleicher Stärke agglutinirt werden. Jedes einzelne Immunserum beeinflusst alle Typhusculturen in der Regel ziemlich gleichmässig und lässt den für den homologen Stamm ermittelten Agglutinationstiter (1:2000 bis $1: 10000)$ auch für die übrigen Culturen in der völlig oder wenigstens annähernd gleichen Weise zu Tage treten. Ein quantitativer Unterschied in dem Verhalten der einzelnen Sera gegenüber dem homologen. Stamm einerseits und den anderen Stämmen andererseits lässt sich kaum finden.

Wie oben erwähnt, sind die Ergebnisse erst nach 20 bis 24 Stunden endgültig. Tabelle VIII giebt einen Ueberblick über den zeitlichen Verlauf des Agglutinationsvorganges bei den einzelnen Culturen.

Tabelle VIII. Serum Gelsenkirchen.

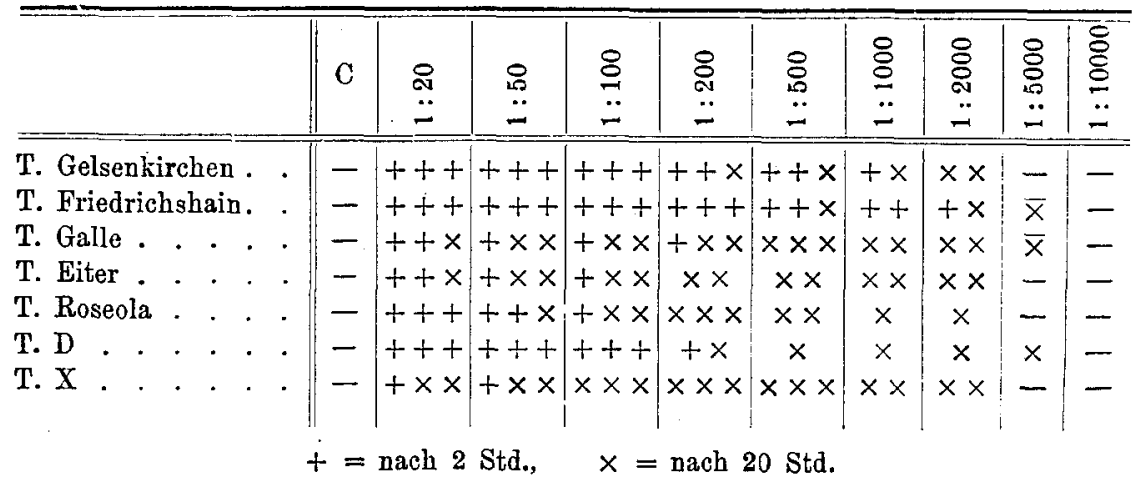

Wollte man sich hier mit einer Betrachtung nach 2 Stunden begnügen, so würde man möglicher Weise zu dem Schlusse gelangen, dass die Culturen "Roseola", ,Eiter" und X keine Typhusbacillen seien, und auch bei den Stämmen D und ,Galle" könnte es zum mindesten zweifelhaft erscheinen. Denn während die Culturen "Gelsenkirchen" und „Friedrichshain" bis zur Verdünnung 1:1000 bezw. 1:2000 agglutinirt werden, ist zur gleichen Zeit die Agglutinationsgrenze bei den übrigen Stämmen auf $1: 50$ bis höchstens $1: 200$ beschränkt. Ganz anders aber fällt das Urtheil aus, wenn man den Vorgang weiter verfolgt und die Röhrchen nach 20 Stunden controlirt. Hier werden, wie ans der Tabelle ersichtlich, alle Stämme fast in gleicher Stärke agglutinirt. Ich kann hinzufügen, dass mitunter schon in einem früheren Stadium, nach etwa 6 bis 8 Stunden, der Process beendet 
und eine Entscheidung möglich ist, möchte aber im Allgemeinen auf Grund eines sehr reichen Beobachtungsmaterials empfehlen, den Versuch nicht vor 20 bis 24 Stunden abzuschliessen. Ich konnte sogar einige Fälle beobachten, wo die Agglutination erst nach 36 Stunden in die Erscheinung trat.

Wir würden also in diesen Beobachtungen eine neue Bestätigung der bemerkenswerthen Thatsache vor uns haben, dass es auch unter den Typhusbacillen leicht und schwer, bezw. rasch und langsam agglutinirbare Stämme giebt. Die mir zur Verfügung stehenden Stämme zeigten nach dieser Richtung ausserordentlich weitgehende Differenzen. Es sei übrigens besonders hervorgehoben, dass nicht etwa irgend welche Eigenschaften des im einzelnen Falle verwendeten Immunserums für die mehr oder minder rasche Agglutination der verschiedenen Stämme verantwortlich zu machen waren, vielmehr lediglich die Natur dieser letzteren selbst. Denn durch jedes beliebige Typhusserum wurden die schwerer agglutinirbaren Stämme („Eiter“, „Galle“, $\mathbf{X}$ ) stets langsamer beeinflusst, als die anderen; ja auch das homologe Immunserum gab die gleichen Resultate. ${ }^{1}$ Endlich bleibe nicht unerwähnt, dass das Bild, welches die verschiedenen Typhusstämme bei der Agglutinationsprüfung gaben, schon bei der einfachen Besichtigung der nicht aufgeschüttelten Reagensröhrchen deutliche Differenzen aufzuweisen pflegte. Auch wenn die Agglutinationsgrenze für alle Culturen die gleiche war, etwa 1:2000, so fand sich gewöhnlich nur bei einigen eine von der stärksten Concentration an deutlich abgestufte Scala, derart, dass die Flüssigkeit in dem ersten oder auch in den zwei, drei ersten Röhrchen völlig klar war, mit reichlichem Sediment, während in den folgenden Proben allmählich fortschreitend der Bodensatz immer geringer, die Flüssigkeit immer trüber wurde, und daher eine scharfe Grenze gegenüber den stark getrübten und nicht mehr agglutinirten Serumverdünnungen kaum erkennbar war. Im Gegensatz hierzu zeigten andere Culturen für die ganze Reihe der agglutinirten Proben eine gleichmässige äussere Beschaffenheit, indem die Röhrchen bei mehr oder minder reichlichem Sediment gewöhnlich ziemlich klar blieben und somit die Agglutinationsgrenze schon bei oberflächlicher Betrachtung ohne Weiteres deutlich hervortreten liessen. Die erste Art des Verhaltens wurde namentlich bei T. „Galle“, „Eiter", $\mathbf{X}$, die letztere bei T. „Friedrichshain“ und "Gelsenkirchen“ beobachtet. Die genauere makroskopische und mikroskopische Untersuchung hat für die Erklärung dieser Differenzen irgend welche Anhaltspunkte nicht ergeben.

1 Vgl. R. I. Cole, Diese Zeitschrift. Bd. XLVI. 


\section{Wirkung der Typhussera gegenüber typhusähnlichen Bakterien.}

Eine zweite Reihe von Versuchen galt der Prüfung des Einflusses, den die Typhusimmunsera auf die verschiedenen typhusähnlichen Stämme auszuüben vermochten. Zur Controle wurden in jedem Falle stets mehrere echte Typhusstämme zur Agglutination mit herangezogen.

Tabelle IX. Serum Gelsenkirchen.

\begin{tabular}{|c|c|c|c|c|c|c|c|c|c|c|c|}
\hline & & C. & $\begin{array}{l}\text { ̊ } \\
\because \\
\end{array}$ & $\begin{array}{l}0 \\
\ddot{2} \\
-\end{array}$ & $\begin{array}{l}\stackrel{8}{0} \\
\dddot{-}\end{array}$ & $\begin{array}{l}\stackrel{8}{\circ} \\
\because \\
-\end{array}$ & $\begin{array}{l}8 \\
8 \\
\ddot{0} \\
-\end{array}$ & $\begin{array}{l}8 \\
0 \\
\ddot{0} \\
-\end{array}$ & $\begin{array}{l}\text { ळे } \\
\text { ஸ. } \\
\ddot{-}\end{array}$ & \begin{tabular}{l}
8 \\
8 \\
\hdashline \\
-1
\end{tabular} & $\begin{array}{l}\stackrel{8}{8} \\
0 \\
\ddot{0}\end{array}$ \\
\hline T. Gelsenkirchen . & & - & $+t+$ & +++ & $++t$ & $+t+$ & +++ & ++ & ++ & $\mp$ & - \\
\hline T. Friedrichshain. & & - & $+t+$ & +++ & +++ & +++ & +++ & ++ & ++ & $\mp$ & - \\
\hline T. Eiter . . . . & & - & $+t+$ & +++ & ++ & ++ & ++ & + & + & + & - \\
\hline Strassburg A . & & - & $+t+$ & +++ & + & - & - & - & - & - & - \\
\hline Strassburg B . & & - & + & $\mp$ & + & - & - & - & - & - & - \\
\hline Schottmüller A & & & & & $\mathrm{i} \subset \mathrm{h}$ & $t g$ & $\mathrm{p} r \ddot{u}$ & $f t$ & & & \\
\hline Schottmüller B & • & - & + & + & ++ & - & - & - & - & 一 & - \\
\hline Saarbrücken. . & . & 一 & ++ & + & + & Ps. & - & - & - & - & - \\
\hline Gärtner . . & & - & + & + & - & - & - & - & - & - & - \\
\hline Coli I. . & & - & ++ & ++ & ++ & + & + & - & - & - & - \\
\hline Coli II. & & - & - & - & - & - & - & - & - & - & - \\
\hline Coli III . & . & - & - & - & - & - & - & - & - & - & - \\
\hline Coli IV. & & - & - & - & - & - & - & - & - & - & - \\
\hline Kruse . . . . . & & - & - & - & - & - & - & - & - & - & - \\
\hline Faec. alcaligenes . & & - & Ps. & Ps. & - & 一 & Ps. & - & Ps. & - & - \\
\hline Nietleben.. & 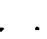 & - & + & $\mp$ & - & - & - & - & - & - & - \\
\hline
\end{tabular}

Tabelle X. Serum Friedrichshain.

\begin{tabular}{|c|c|c|c|c|c|c|c|c|c|c|}
\hline & C. & \begin{tabular}{l}
8 \\
\hdashline \\
$ت$
\end{tabular} & $\stackrel{\stackrel{\circ}{:}}{=}$ & $\underset{ت}{\stackrel{8}{ت}}$ & $\ddot{-}$ & & & $\ddot{\nabla}$ & $\begin{array}{l}8 \\
8 \\
0 \\
\ddot{0} \\
=\end{array}$ & $\mid \begin{array}{l}0 \\
\tilde{E} \\
\ddot{0}\end{array}$ \\
\hline
\end{tabular}

T. Friedrichshain. . $-1+++++++++1+++++\mid+++++1+$ T. Gelsenkirehen. . I $-++++++++++1+++++++++++++\mp$ T. Galle . . . . $-1+++++++\mid++++1+-1$ Strassburg A. . - + + + - - - -

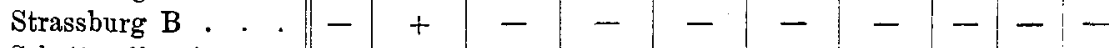
Schottmüller A . Saarbrücken. . . . $-1+++++\mp$ Ps. - - Ps. Gärtner... spontane Agglatination Coli I. Coli IV

Kruse. Nietleben 
Tabelle XI. Serum Galle.

\begin{tabular}{|c|c|c|c|c|c|c|c|c|c|c|}
\hline & c. & $\stackrel{\text { ̊ㅗ }}{-}$ & 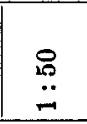 & $\begin{array}{l}\stackrel{8}{\dddot{Z}} \\
\end{array}$ & 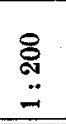 & $\begin{array}{l}8 \\
\text { I. } \\
\end{array}$ & $\begin{array}{l}\stackrel{8}{8} \\
\stackrel{0}{-1} \\
-1\end{array}$ & $\begin{array}{l}\stackrel{8}{\circ} \\
\text { : } \\
\ddot{\sim}\end{array}$ & $\begin{array}{l}8 \\
\text { 号 } \\
\stackrel{4}{-1} \\
\end{array}$ & $\begin{array}{l}\stackrel{\emptyset}{0} \\
\vdots \\
\ddot{-}\end{array}$ \\
\hline T. Galle & - & $++t$ & ++ & ++ & ++ & ++ & + & + & + & - \\
\hline T. $\mathbf{R}$ & - & $++t$ & +++ & ++ & $+t$ & ++ & ++ & + & - & - \\
\hline T. Eiter & - & +++ & ++ & ++ & ++ & + & + & + & - & - \\
\hline Strassburg A & - & ++ & $F$ & - & - & - & - & - & - & - \\
\hline Strass & - & + & - & - & - & - & - & - & - & - \\
\hline $\mathrm{A}$ & - & + & - & - & - & - & - & - & - & - \\
\hline Schottmüller B & - & + & - & - & - & - & - & - & - & - \\
\hline Saarbrücken. . & - & $+t$ & + & + & Ps. & Ps. & - & - & - & - \\
\hline Gärtner . . & - & + & + & - & - & - & Ps. & Ps. & Ps. & - \\
\hline & - & ++ & + & + & - & - & - & - & - & - \\
\hline Coli & - & - & - & - & - & - & - & - & - & - \\
\hline & - & - & - & - & - & - & - & - & - & - \\
\hline & - & - & - & - & - & - & - & - & - & - \\
\hline Faec. alcalig. & 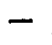 & Ps. & Ps. & Ps. & Ps. & - & - & Ps. & - & Ps. \\
\hline
\end{tabular}

Tabelle XII. Serum Eiter.

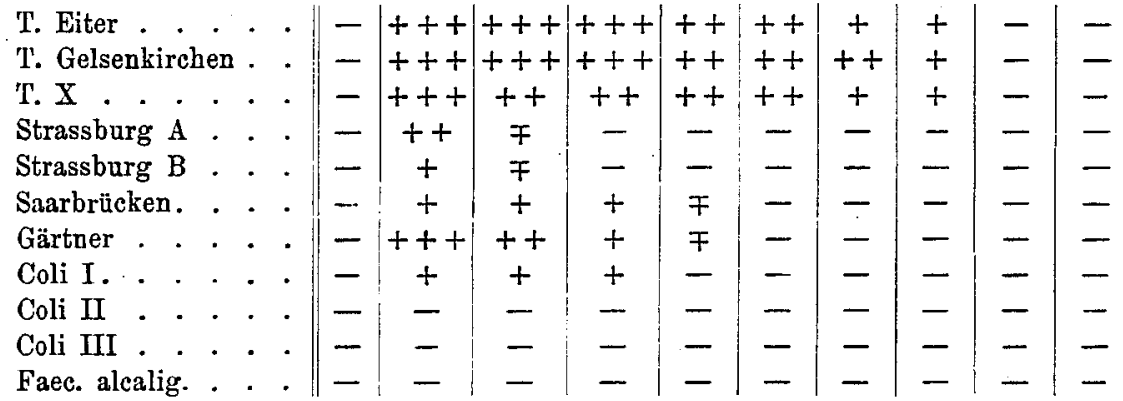

Tabelle XIII. Serum Roseola.

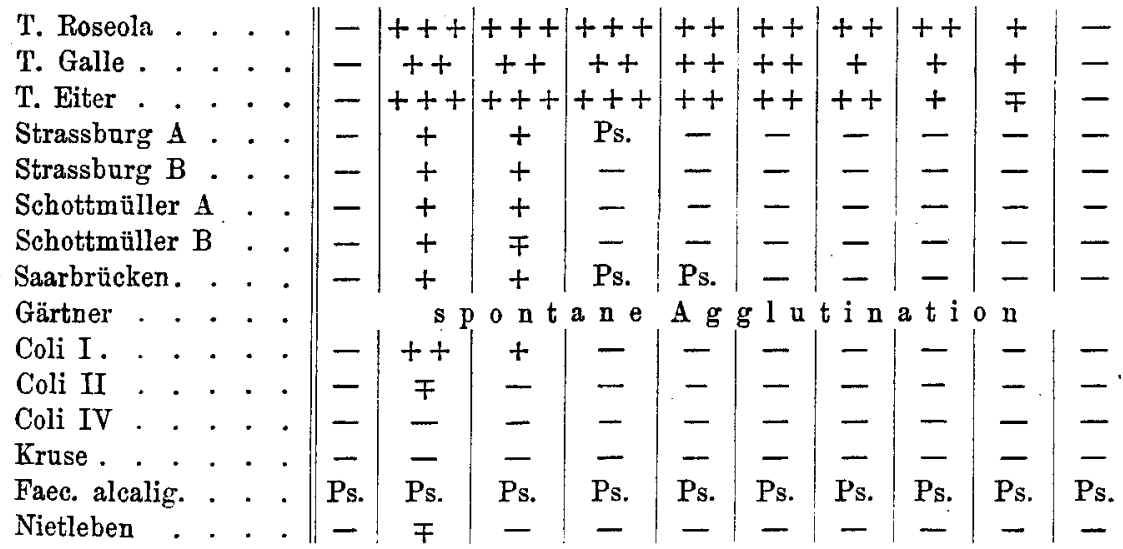


Tabelle XIV. Serum D.

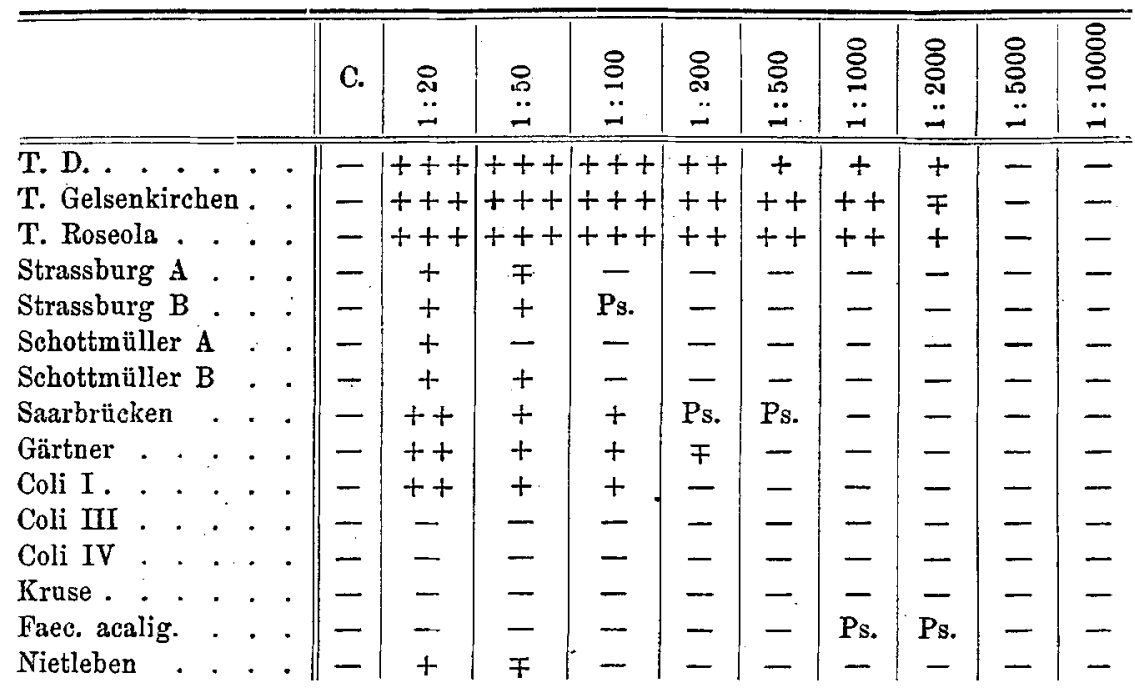

Tabelle XV. Serum X.

\begin{tabular}{|c|c|c|c|c|c|c|c|c|c|c|}
\hline T. $x$ & - & $++t$ & ++ & + & + & + & + & - & - & - \\
\hline T. Eiter . & & $+t$ & $+t$ & + & + & + & $\mp$ & - & - & - \\
\hline Strassburg B & - & + & Ps. & Ps. & Ps. & - & - & - & - & - \\
\hline Schottmüller A & - & + & $\mp$ & - & - & - & - & - & - & - \\
\hline Coli I. . . & - & $+t$ & + & + & - & - & - & - & - & - \\
\hline Coli III & - & - & - & - & - & - & - & - & - & - \\
\hline Faec. alcalig. & - & - & - & - & - & - & - & - & - & - \\
\hline Nietleben. & - & $\mp$ & - & - & - & - & - & - & - & - \\
\hline
\end{tabular}

Schon eine oberflächliche Betrachtung der Tabellen lässt auf den ersten Blick einen deutlichen Unterschied in der Wirkungsweise der geprüften Sera gegenüber Typhusbacillen einerseits und den typhusähnlichen Arten andererseits klar hervortreten. Obwohl sämmtliche Sera a uf echte Typhusbacillen eine hochgradige Agglutinationswirkung aus. übten, versagten sie gegenüber den andersartigen Stämmen in der Regel schon bei mässigen Verdünnungsgraden und gaben damit ein durchaus specifisches Verhalten zu erkennen.

Wie aus den verschiedenen Tabellen hervorgeht, zeigten sich die meisten Stämme, nämlich Dysenteriebacillus, B. coli II, coli III und coli IV, B. Nietleben, B. faecalis alcaligenes, vor allen Dingen auch die verschiedenen Stämme von Paratyphusbacillen (Strassburg A und B, Schottmüller $A$ und B) gegenüber dem Typhusserum ganz und gar unemplindlich oder wurden höchstens in der Concentration 1:20-1:50, ausnahmsweise 1:100 schwach und keineswegs regelmässig beeinflusst. Nur bei dem 
Gärtner'schen Bacillus enteritidis, dem B. Saarbrücken und B. coli I stieg gelegentlich der Agglutinationswerth etwas höher, indem noch Verdünnungen ron $1: 100$ bis $1: 200$, bei $B$. coli $I$ selbst einmal $1: 500$ diese Culturen agglutinirten.

Indessen, selbst wenn wir die höchsten Agglutinationsziffern berücksichtigen, so steht doch in jedem Fulle die Agglutination dieser typhusähnlichen Bakterien durch echte Typhussera rela ti v auf einer sehr niedrigen Stufe, insofern als das gleiche Serum gegenüber den Typhusstämmen stets noch in 10- bis 20 fach stärkerer Verdünnung wirksam war. Beispielsweise bewegte sich der Agglutinationstiter derjenigen Sera, welche den B. Saarbrücken, B. Gärtner und Coli $I$ in einer Verdünnung ron 1:200 agglutinirten, bei der Prüfung mit echten Typhusbacillen zwischen 1:2000 und $1: 5000$.

Iran sieht daraus, dass zwischen den Typhusstämmen und den anderen von mir untersuchten Arten eine ziemlich scharfe Scheidung nachweisbar ist. Im Vergleich mit der specifischen Typhusagglutination spielen eben die an sich vielleicht nicht ganz geringfügigen Agglutinationswerthe von $1: 100$ bis $1: 200$ bei den andersartigen Bakterien in unseren Versuchen keine Rolle. Als besonders bemerkenswerth möchte ich hervorheben, dass mit dem Steigen des specifischen Agglutinationstiters des Serums eine Erhöhung des Agglutinationswerthes gegenüber den typhusähnlichen Bakterien in der Regel nicht zu beobachten war. Neine Versuche haben die von anderen Seiten öfters ausgesprochene Behauptung, dass die Nebenwirkungen und Gruppenreactionen um so stärker hervorzutreten pflegen, je hochwerthiger ein Immunserum ist, für den Fall der Typhusagglutination nicht bestätigen können. Es wurde rielmehr nicht selten beubachtet, dass z. B. ein Typhusserum von dem Titer 1:10000 die andersartigen Bakterien nur bis zur gleichen Grenze mitagglutinirte, wie ein $10 \mathrm{fach}$ schwächeres Serum $(1: 1000)$, eine Feststellung, die gerade den streng specifischen Charakter der Agglatination noch weiter zu stützen geeignet sein dürfte. (Vgl. Tab. X, XIV.)

Im Uebrigen liess die bei den Typhusstämmen und den anderen Bakterien auftretende Agglutination nach ihrem Wesen einen Unterschied nicht erkennen. Eine regelmässig ausgeführte mikroskopische Untersuchung bei B. typhi einerseits, B. enteritidis, B. coli I, Saarbrücken andererseits lieferte im grossen Ganzen die nämlichen Befunde. Nur zeigte sich, dass bei dem B. Saarbrücken fast immer neben den agglutinirten auch ziemlich reichliche isolirte, unbeeinflusste Stäbchen zu sehen waren. 


\section{Einfluss des Serums der typhusähnlichen Arten auf Typhns- und typhusähnliche Stämme.}

Noch auf einem anderen Wege war es möglich die agglutinirende Wirkung der Immunsera auf ihren specifischen Charakter zu prüfen, nämlich durch die Gegenprobe. Zu diesem Zwecke wurden die Immunsera der typhusähnlichen Culturen in ihrer Wirkung auf den homologen Stamm sowohl, wie auf die anderen, vor Allem die Typhusstämme untersucht.

Ich habe diese vergleichenden Versuche in ausgedehntem Maasse angestellt und oft wiederholt.

Tabelle XVI. Serum Coli I.

\begin{tabular}{|c|c|c|c|c|c|c|c|c|c|c|c|c|}
\hline & & & C. & $\begin{array}{l}\text { 尺ิ } \\
\because \\
-\end{array}$ & \begin{tabular}{r}
8 \\
\hdashline \\
\end{tabular} & $\begin{array}{l}\stackrel{8}{0} \\
\ddot{-} \\
-\end{array}$ & $\begin{array}{l}\stackrel{8}{\circ} \\
\stackrel{\text { }}{ } \\
-\end{array}$ & 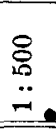 & $\begin{array}{l}8 \\
\stackrel{8}{-} \\
\end{array}$ & $\begin{array}{l}\text { ¿े. } \\
\text { - } \\
-\end{array}$ & \begin{tabular}{l}
8 \\
8 \\
\hdashline \\
\hdashline \\
\end{tabular} & \begin{tabular}{l}
8 \\
8 \\
\hdashline \\
\hdashline
\end{tabular} \\
\hline Coli I, . . . & . & . & - & $++t$ & ++ & ++ & + & + & + & + & - & - \\
\hline Coli II . . . & . & & - & + & - & - & - & - & - & - & 一 & - \\
\hline Coli III . . . & - & - & - & - & - & - & - & - & - & - & - & - \\
\hline Coli IV . . . & . & . & - & - & - & - & - & - & - & - & - & - \\
\hline T. Gelsenkirchen & . & . & - & + & - & - & - & - & - & - & - & - \\
\hline T. Friedrichshair & a. & . & - & + & - & - & - & - & - & - . & - & - \\
\hline T. Galle. . . & . & & - & + & - & - & - & - & 一 & - & - & - \\
\hline T. Eiter . . & . & . & - & + & - & - & - & - & - & - & - & - \\
\hline $\mathrm{T} . \mathrm{D} \cdot \cdot$ & . & . & - & - & - & - & 一 & - & - & - & - & - \\
\hline T. X . . & . & - & - & $\mp$ & 一 & - & - & - & - & - & - & - \\
\hline Strassburg A . & . & . & - & + & + & $\mp$ & - & - & - & - & - & - \\
\hline Strassburg: $\mathrm{B}$ & . & & & & & i c & $t g$ & $\mathrm{p}$ & ii $f t$ & & & \\
\hline Schottmüller A & . & . & - & ++ & + & $\mp$ & - & - & - & - & - & - \\
\hline Schottmüller B & . & . & - & + & + & $\mp$ & - & - & 一 & - & - & - \\
\hline Saarbrücken. . & . & . & - & ++ & + & + & $\mp$ & - & - & - & - & - \\
\hline Gärtner. . . & . & . & - & 7 & - & - & - & - & - & - & - & - \\
\hline Kruse. . & . & - & - & - & - & - & - & - & - & - & - & - \\
\hline Faec. alcalig. . & $\cdot$ & $\cdot$ & - & - & - & - & - & - & - & - & - & - \\
\hline Nietleben . . & . & • & - & - & - & - & - & - & - & - & - & - \\
\hline
\end{tabular}

Tabelle XVII. Serum Gärtner.

\begin{tabular}{|c|c|c|c|c|c|c|c|c|c|c|}
\hline Gärtner . . . & - & ++ & ++ & + & + & + & + & $\mp$ & - & - \\
\hline T. Friedrichshain. & - & + & + & - & - & - & - & - & 一 & - \\
\hline T. Galle . . . & - & + & $\mp$ & - & - & - & - & - & - & - \\
\hline T. Roseola . & - & + & 一 & - & - & - & - & - & - & - \\
\hline T. D . . . & - & + & - & - & - & - & - & - & - & - \\
\hline T. $\mathrm{X}$. & - & + & + & - & - & - & - & - & - & - \\
\hline Strassburg A & - & $\mp$ & - & - & 一 & $\dot{-}$ & 一 & - & - & - \\
\hline Strassburg B . & - & + & $\mp$ & - & - & - & - & - & - & - \\
\hline Schottmüller A & - & - & - & 一 & - & - & - & - & - & - \\
\hline
\end{tabular}


V. Porcme:

Tabelle XVII. Serum Gärtner. (Fortsetzung.)

\begin{tabular}{|c|c|c|c|c|c|c|c|c|c|c|c|}
\hline & & C. & $\begin{array}{l}\stackrel{\leftrightarrow}{*} \\
\ddot{\sim} \\
\end{array}$ & $\begin{array}{l}\stackrel{8}{\circ} \\
\because \\
\end{array}$ & $\begin{array}{l}\stackrel{8}{0} \\
\ddot{0} \\
\end{array}$ & $\begin{array}{l}8 \\
\stackrel{8}{0} \\
\ddot{-} \\
\end{array}$ & $\begin{array}{l}8 \\
\stackrel{0}{\circ} \\
\because\end{array}$ & $\begin{array}{l}\oint_{0} \\
\ddot{n} \\
\ddot{-}\end{array}$ & 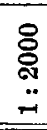 & 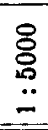 & $\begin{array}{l}8 \\
8 \\
8 \\
8 \\
- \\
-\end{array}$ \\
\hline Schottmüller $\mathrm{E}$ & & - & + & + & + & - & - & - & - & - & - \\
\hline Saarbrücken & & - & + & $\mp$ & - & - & - & - & - & - & - \\
\hline Coli I. . . & & - & + & + & - & - & - & - & - & - & - \\
\hline Coli II. & & - & - & - & - & 一 & - & - & - & - & - \\
\hline Coli IV . & & - & - & - & - & - & - & - & - & - & - \\
\hline Krase . . & & - & - & - & - & - & - & - & - & - & - \\
\hline Faec. alcalig. & & - & - & 一 & - & - & - & - & - & - & - \\
\hline Nietleben & & - & - & - & - & - & - & - & - & - & - \\
\hline
\end{tabular}

Tabelle XVIII. Serum Faecalis alcaligenes.

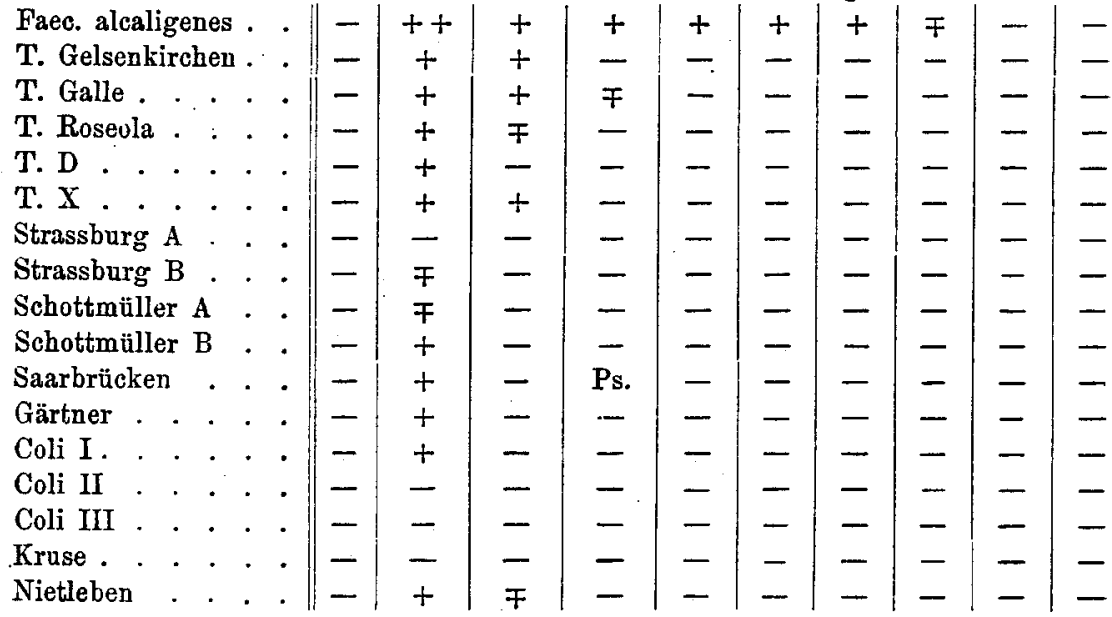

Tabelle XIX. Serum Coli II:

Coli II

Coli I.

Coli III

\begin{tabular}{|c|c|c|c|c|c|c|c|}
\hline$++1+++$ & ++ & + & + & + & - & - & - \\
\hline - & - & Ps. & - & - & Ps. & - & - \\
\hline - & - & - & - & - & - & - & - \\
\hline - & - & - & - & - & - & Ps. & - \\
\hline - & - & - & - & - & - & - & - \\
\hline & - & - & - & - & - & - & - \\
\hline & - & - & - & - & - & - & - \\
\hline & - & - & - & $\overline{-}$ & - & - & - \\
\hline & - & - & - & - & - & - & - \\
\hline & - & - & - & - & - & - & - \\
\hline & - & - & - & - & - & - & \\
\hline & - & - & - & - & \pm & 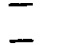 & \\
\hline & - & - & - & - & - & - & \\
\hline
\end{tabular}


Tabelle XX. Serum Nietleben.

\begin{tabular}{|c|c|c|c|c|c|c|c|c|c|c|}
\hline & C. & 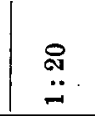 & \begin{tabular}{l}
$\circ$ \\
\hdashline \\
-1
\end{tabular} & \begin{tabular}{l}
$\stackrel{8}{0}$ \\
\hdashline \\
$ت$
\end{tabular} & 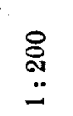 & 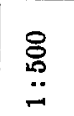 & 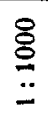 & 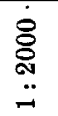 & $\begin{array}{l}\stackrel{8}{\circ} \\
\stackrel{0}{-}\end{array}$ & $\begin{array}{l}0 \\
0 \\
0 \\
\ddot{-}\end{array}$ \\
\hline Nietleben & - & $1+++$ & +++ & +++ & ++ & ++ & + & - & - & - \\
\hline T. Ga & - & $1-$ & - & - & - & - & - & - & - & - \\
\hline T. Roseola & - & - & - & - & - & - & - & - & - & - \\
\hline F. Eiter . & - & - & - & - & - & - & - & - & - & - \\
\hline T. $\mathrm{X}$ & - & - & - & - & - & - & - & - & - & - \\
\hline Strassburg $A$ & - & - & - & - & - & - & - & - & - & - \\
\hline Strassburg B & - & - & - & - & - & - & $\dot{-}$ & - & - & - \\
\hline Schottmüller A & - & - & - & - & - & - & - & - & - & - \\
\hline Schottmüller B & - & - & - & - & - & - & - & - & - & - \\
\hline Saarbrücken . & - & - & - & - & - & - & - & - & - & - \\
\hline Gärtner . . & - & - & - & - & - & - & - & - & - & - \\
\hline Coli & - & + & + & - & - & - & - & - & & - \\
\hline Coli I & - & $\mp$ & - & - & - & - & - & - & - & - \\
\hline & - & - & - & - & - & - & - & - & & - \\
\hline Coli IV & - & - & - & - & - & - & - & - & - & - \\
\hline Kruse. & & - & - & - & & - & - & - & & - \\
\hline
\end{tabular}

Tabelle XXI. Serum Schottmüller B.

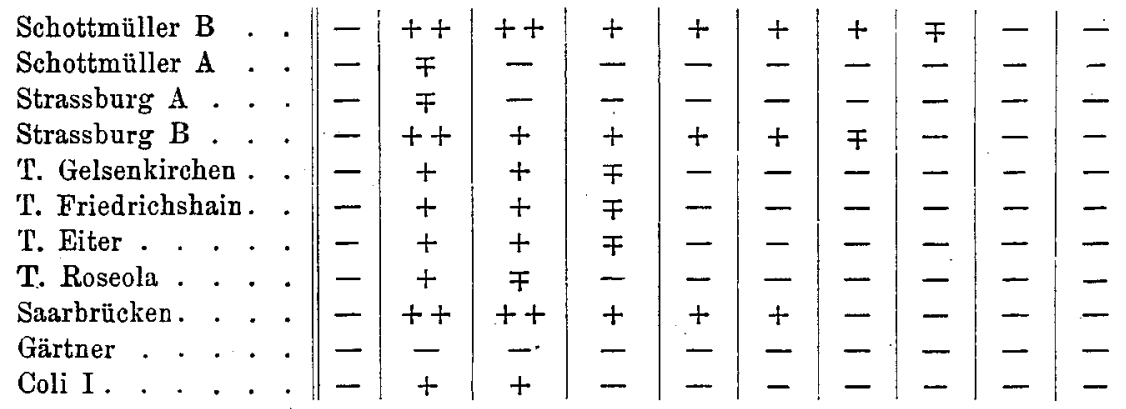

\section{Tabelle XXII. Serum Strassburg B.}

\begin{tabular}{|c|c|c|c|c|c|c|c|c|c|c|c|}
\hline Strassburg B & & - & +++ & ++ & + & + & + & $\mp$ & - & - & - \\
\hline Strassburg A & & - & ++ & $\mp$ & - & - & - & - & - & - & - \\
\hline Schottmüller A & • & - & ++ & $\mp$ & - & - & - & - & - & - & - \\
\hline Sehottmüller B & & - & ++ & + & + & + & $\mp$ & - & - & - & - \\
\hline T. Gelsenkirchen . & . & - & $+t$ & + & - & - & - & - & - & - & - \\
\hline T. Friedrichshain. & . & - & $+t+$ & ++ & + & $\mp$ & - & - & - & - & - \\
\hline T. Galle. . & . & - & + & + & + & $\mp$ & - & - & - & - & - \\
\hline T. Roseola. & . & - & + & + & - & - & - & - & - & 一 & - \\
\hline T. Eiter. . & • & - & ++ & ++ & $\mp$ & - & - & - & - & - & - \\
\hline T. D . . & • & - & + & + & $\mp$ & - & - & - & - & 一 & - \\
\hline Saarbrücken & $\cdot$ & - & + & + & + & + & + & - & - & - & - \\
\hline Gärtner . . & & - & + & + & - & - & - & - & - & - & - \\
\hline Coli I. & & - & $+t$ & ++ & + & - & - & - & - & - & - \\
\hline
\end{tabular}


Tabelle XXIII. Serum Saarbrücken.

\begin{tabular}{|c|c|c|c|c|c|c|c|c|c|c|c|}
\hline & & C. & $\begin{array}{l}\text { 尺े } \\
\ddot{-}\end{array}$ & $\begin{array}{l}\circ \\
\dddot{0} \\
\ddot{-}\end{array}$ & $\underset{8}{\stackrel{8}{\Xi}}$ & $\begin{array}{l}\text { \& } \\
\text {. } \\
\because\end{array}$ & $\begin{array}{l}8 \\
0 \\
\ddot{0} \\
\ddot{-}\end{array}$ & \begin{tabular}{l}
$\stackrel{8}{8}$ \\
\hdashline \\
$\ddot{0}$ \\
-1
\end{tabular} & 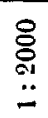 & $\begin{array}{l}8 \\
8 \\
0 \\
\ddot{0} \\
-0\end{array}$ & $\begin{array}{l}8 \\
\bar{\delta} \\
\ddot{0}\end{array}$ \\
\hline Saarbrücken & & - & $1+++$ & $1+++$ & $1+++$ & ++ & + & + & - & - & - \\
\hline T. Friedrichshain & & - & +++ & ++ & $+t$ & + & + & - & - & - & - \\
\hline T. Galle. . & & - & $+t$ & + & + & - & - & - & - & - & - \\
\hline T. Roseola . & . & - & ++ & + & + & + & - & - & - & - & - \\
\hline T. D . . . & . & 一 & ++ & + & + & $\mp$ & - & - & - & - & - \\
\hline Strassburg A . & . & - & + & $\mp$ & - & - & - & - & - & - & - \\
\hline Strassburg B . & . & 一 & $+t+$ & +++ & ++ & + & + & - & - & - & - \\
\hline Schottmïller A & . & - & + & + & - & Ps. & - & - & - & - & - \\
\hline Schottmüller B & . & - & ++ & + & + & + & + & - & - & - & - \\
\hline Gärtner . . & 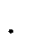 & 一 & + & $\mp$ & - & - & - & - & 一 & - & - \\
\hline Coli I. . . & & - & ++ & ++ & + & + & - & - & - & - & - \\
\hline Coli IV. & & - & - & - & - & - & - & - & - & - & - \\
\hline Kruse . . & & - & - & - & - & - & - & - & - & - & - \\
\hline Nietleben . & & - & $\mp$ & - & - & - & - & - & - & - & - \\
\hline
\end{tabular}

'T i belle XXIV. Serum Schottmüller A.

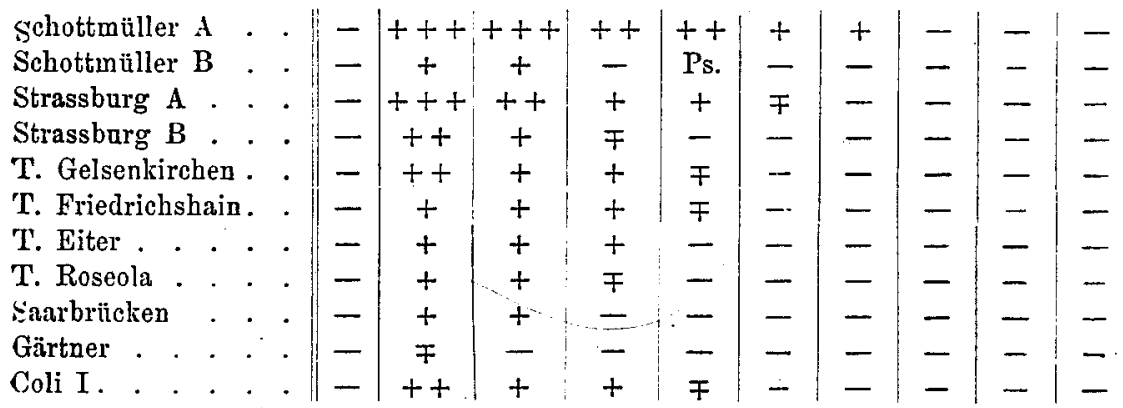

Es ergab sich dabei zunächst, wie Tabelle XVI und XVII lehren, dass das Serum Coli I, sowie das Serum Bac. enteritidis Gärtner, beide ron dem Titer 1:2000, deutlich specifisch auf den homologen Stamm wirkten, insofern als sie ausser der gleichen Cultur alle übrigen gar nicht oder nur bis zu einer mässigen Grenze $(1: 100$ bis $1: 200)$ beeinflussten und besonders gegenüber den Typhusbakterien keine nennenswerthe agglutinirende Kraft verriethen.

Ganz ausdrücklich sei auch darauf hingewiesen, dass das Serum Coli I nur den homologen, nicht aber die andern Colistämme agglutinirte. Diese in zahlreichen Versuchen regelmässig constatirte und in ganz analoger Weise auch für ein anderes Coliserum (Tabelle XIX) bestätigte Thatsache steht durchaus im Einklarg mit einigen auch von anderer Seite nach dieser Richtung gemachten Erfahrungen. Sie weist unzwei- 
deutig darauf hin, dass die agglutinirende Wirkung des Coliserums gewissermaassen den höchsten Grad strenger Specifität darstellt und höchsten s den gleichen Stamm trifft, selten aber - in meinen Versuchen sogar niemals - sich auf andere Culturen erstreckt. Die vorerwähnten Culturen, Coli I, II, III, IV, repräsentirten, wie nochmals betont sei, völlig typische Vertreter der Colibakterien.

Mit der gleichen oder fast noch grösserer Deutlichkeit tritt die streng specifische Abgrenzung der Agglutinationswirkung bei den mit Bact. coli II, Faecalis alcaligenes, Nietleben erzeugten Immunseris zu Tage (vgl. Tabelle XVIII, XIX, XX). Hier ist der Unterschied ein in die Augen springender und geradezu überraschender, weil in allen Fällen die Agglutination fast ausschliesslich auf den homologen Stamm beschränkt. bleibt und selbst in stärkeren Serumconcentrationen anderen Culturen gegenüber versagt.

Anders dagegen liegen die Verhältnisse bei den nunmehr folgenden Prüfungen (vgl. Tabelle XXI bis XXIV), welche sich auf die Wirkung der Immunsera Strassburg B, Schottmüller A und B und Saarbrücken beziehen. Diese Ergebnisse erfordern eine etwas eingehendere Betrachtung.

Verhältnissmässig klar und eindeutig stellen sich noch die mit Serum Schottmüller B erbaltenen Ergebnisse dar. Hier zeigen die Stämme Strassburg B und Saarbrücken eine von dem für den homologen Stamm ermittelten Agglutinationstiter nicht allzu sehr abweichende Beeinflussung. Diese drei Stämme würden sich somit, in Uebereinstimmung mit der auch von anderen Seiten ausgesprochenen und heute wohl allgemein anerkannten Aunahme, als identische Bakterienarten charakterisiren lassen. Die sonst geprüften Culturen der Tabelle XXI bleiben dagegen mit dem Agglutinationswerth von höchstens 1:100 um das 20 fache binter der Cultur Schottmüller B zurück.

Weniger scharf treten die specifischen Unterschiede bei dem Serum Strassburg B zu Tage (Tabelle XXII). Zwar lässt sich auch hier die Identität der Culturen Strassburg B, Schottmüller B und Saarbrūcken auf den ersten Blick aus der annähernd gleichen Agglutinationshöhe ableiten, doch werden andererseits einige Typhusstämme (,Friedrichshain“ und ,Galle") ungewöhnlich hoch beeinflusst $(1: 200)$.

Noch rerwickelter und geradezu widersprechend erscheinen die in Tabelle XXIII mit Serum Saarbrücken angeführten Versuche. Die Culturen Saarbrücken, Schottmüller B und Strassburg B werden hier auch wieder in gleicher Stärke agglutinirt $(1: 1000$ bezw. $1: 500)$, indessen steht ein Typhusstamm (T. Friedrichshain) mit seiner Agglutinirbarkeit auf gleicher Höhe $(1: 500)$ und drei weitere Culturen (T. Roseola, D. und B., Coli I) bleiben nur wenig dahinter zurück $(1: 200)$. 
Ich möchte besonders darauf hinweisen, dass ich die in den Tab. XXII und XXIII mitgetheilten Versuche, deren Resultat zunächst auffallend und unerwartet war, verschiedene Male wiederholt und dabei stets das gleiche Ergebniss erhalten habe. Um jedem Zweifel an der einwandfreien Beschaffenheit der Culturen und des Serums zu begegnen, wurden die einzelnen Stämme nochmals zu Platten verarbeitet, von isolirten Colonieen neue Reinculturen angelegt und mit diesen die Herstellung des Immunserums und die Agglutinationsprüfung rorgenommen. Auch hier genau das nämliche Ergebniss!

Endlich sei noch auf Tabelle XXIV hingewiesen, welche zwar deutlich die Identität der Culturen Schottmüller A und Strassburg A ergiebt, daneben aber eine hohe Mitagglutination der Typhusstämme Gelsenkirchen und Friedrichshain, sowie des B. coli I hervortreten lässt.

Die eben kurz erörterten Verhältnisse entsprechen somit im Wesentlichen den Befunden, welche auch andere Autoren in dieser Hinsicht erheben konnten. Von verschiedenen Seiten ist mit Hülfe der Paratyphusimmunsera eine nicht unerhebliche Mitagglutination echter Typhusbacillen constatirt worden (Conradi, v. Drigalski und Jürgens, Korte, Jürgens u. A.). Immerhin möchte ich glauben, dass in meinen eigenen Versuchen rielleicht in Folge unzureichender Wirksamkeit der benutzten Immunsera die Verhältnisse sich besonders ungünstig gestaltet haben. Die Grenze, bis zu welcher manche der heterologen Culturen mit beeinflusst wurden $(1: 200)$, stellt an sich einen Werth dar, der, wie wir bei der Prüfung der streng specifischen Typhussera sahen (Tabelle IX bis $\mathrm{XV}$ ), nicht als ein zu erheblicher angesehen werden kann, vielmehr nur im Vergleich mit dem Agglutinationstiter des Serums für die homologe Cultur als ungewöhnlich hoch erscheinen könnte. Es würde mit anderen Worten, wie ich vermuthe, wohl möglich gewesen sein, mit einem wirksameren Immunserum der Culturen Schottmüller A und Saarbrücken, etwa von dem Titer 1:5000 bis 1:10000, schärfere Unterschiede und deutlichere specifische Abgrenzungen der einzelnen Gruppen zu erzielen. Meine zahlreichen Versuche und Bemühungen haben mich indessen insofern im Stich gelassen, als es mir trotz lange fortgesetzter Immunisirung der Thiere nicht gelingen wollte, ein derartig hochwerthiges Serum zu erlangen, und mussten schliesslich aus äusseren Gründen abgebrochen werden. ${ }^{1}$ Sehr bemerkenswerth erscheinen unter diesem Gesichtspunkt die Ergebnisse, welche Korte mit hochwerthigen Paratyphusimmunseris

1 So erklärt sich auch, dass ein Versuch mit dem Serum Strassburg A in den obigen Tabellen nicht aufgeführt ist. Es gelang mir nicht, ein annähernd hochwerthiges Immunserum herzustellen. 
erzielte, indem diese letzteren bei einem Agglutinationstiter von 1:5000, $1: 10000,1: 20000$ und selbst 1:160000 Typhusbacillen in den Grenzen von $1: 320$ bis höchstens 1:640 agglutinirten. Für die Berechtigung meiner Anschauung glaube ich ferner aber eine Stätze einmal in der Wirkung des Immunserums Schottmüller B zu finden, das von den hier in Frage stehenden Seris das stärkste war $(1: 2000)$ und zugleich die eindeutigsten Resultate lieferte, andererseits aber auch in den Erfahrungen, die sich mir ganz allgemein bei der Verwendung minderwerthiger Sera ergeben haben.

Ich habe nämlich bei der Prüfung verschiedener schwächerer Sera beobachten können,' dass sie sich nicht dazu eignen, Agglutinationsprüfungen vorzunehmen und Artunterschiede bei ähnlichen Bakterien festzustellen.

Tabelle XXV. Serum Strassburg A.

\begin{tabular}{|c|c|c|c|c|c|c|c|c|c|c|c|}
\hline & & C. & $\begin{array}{l}\text { 尺े } \\
\ddot{-}\end{array}$ & $\begin{array}{l}8 \\
\because \\
\because\end{array}$ & $\begin{array}{l}8 \\
\stackrel{-}{*}\end{array}$ & $\begin{array}{l}\stackrel{\circ}{\circ} \\
\ddot{-}\end{array}$ & $\begin{array}{l}8 \\
\text { 足 } \\
\because \\
\end{array}$ & \begin{tabular}{l}
8 \\
0 \\
\hdashline
\end{tabular} & $\begin{array}{l}\stackrel{8}{\circ} \\
\text { ․ } \\
\ddot{\sim}\end{array}$ & $\begin{array}{l}8 \\
8 \\
: \\
\ddot{6}\end{array}$ & $\begin{array}{l}8 \\
8 \\
8 \\
\ddot{8}\end{array}$ \\
\hline Strassburg A . & . & - & +++ & +++ & + & + & - & - & - & - & - \\
\hline Strassburg B . & . . & - & + & + & + & - & - & - & - & - & - \\
\hline Schottmüller A & . & - & ++ & + & + & - & - & - & - & - & - \\
\hline Schottmüller B & . . & - & ++ & + & + & $\mp$ & - & - & - & - & - \\
\hline Saarbrücken . & . & - & ++ & + & + & + & - & - & - & - & - \\
\hline Friedrichshain . & . & - & ++ & + & + & + & - & 一 & - & 一 & - \\
\hline Roseola . . . & . & - & + & + & + & - & - & - & - & - & - \\
\hline Eiter . . & . & - & ++ & ++ & + & - & - & - & - & - & - \\
\hline Coli I. . & . & - & ++ & ++ & + & + & - & - & - & - & - \\
\hline Coli II . . & . & - & - & - & - & - & 一 & - & - & - & - \\
\hline Nietleben . & . . & - & - & - & - & - & - & - & - & - & - \\
\hline
\end{tabular}

Tabelle XXVI. Serum Strassburg B.

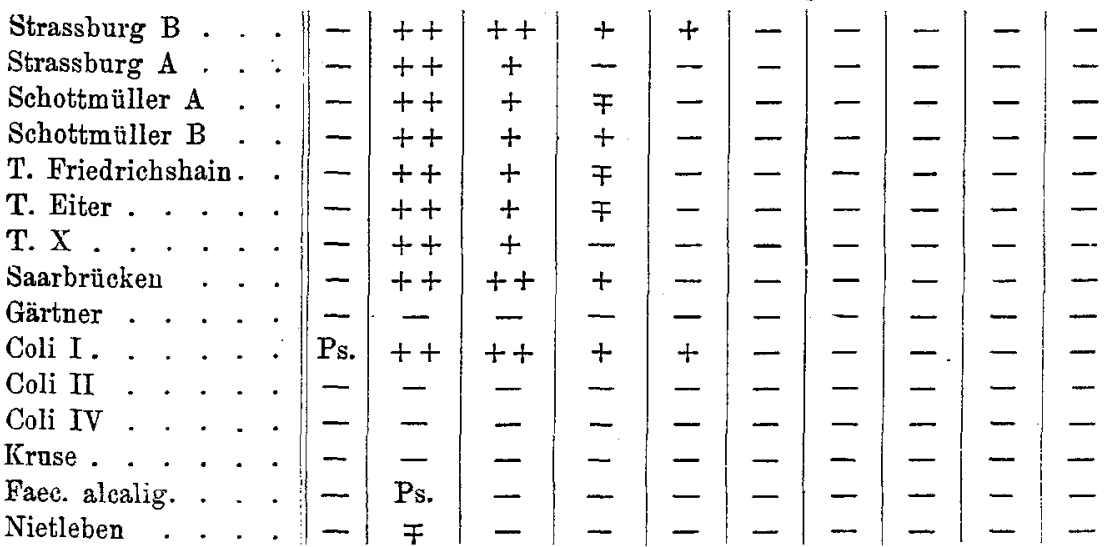


Tabelle XXVII. Serum Schottmüller B.

\begin{tabular}{|c|c|c|c|c|c|c|c|c|c|c|c|c|}
\hline & & & C. & $\underset{\sim}{\stackrel{0}{*}}$ & $\begin{array}{l}8 \\
\ddot{0} \\
\ddot{-}\end{array}$ & $\begin{array}{l}8 \\
\stackrel{8}{-} \\
-\end{array}$ & $\begin{array}{l}\text { 尺े } \\
\text { - } \\
-\end{array}$ & $\begin{array}{l}8 \\
0 \\
- \\
-\end{array}$ & $\begin{array}{c}8 \\
8 \\
\dddot{8} \\
=\end{array}$ & $\begin{array}{l}8 \\
\text { §్ర } \\
\dddot{-} \\
\end{array}$ & \begin{tabular}{l}
8 \\
8 \\
\hdashline \\
-0 \\
\end{tabular} & \begin{tabular}{l}
8 \\
$\varnothing$ \\
0 \\
\hdashline \\
\end{tabular} \\
\hline Schottmüller B & . & . & - & ++ & + & + & $\mp$ & - & - & - & - & - \\
\hline Schottmüller $A$ & & . & - & + & Ps. & - & - & - & - & - & - & - \\
\hline Strassburg A & & . & - & + & $\mp$ & - & - & - & - & - & - & - \\
\hline Strassbarg B & & . & - & + & + & + & - & - & - & - & - & - \\
\hline T. Roseola . & & . & - & ++ & + & $\mp$ & - & - & - & - & - & - \\
\hline T. Eiter . & . & . & - & + & + & - & - & - & - & - & - & - \\
\hline T. D . . & . & . & - & $+t$ & + & - & - & - & - & - & - & - \\
\hline Saarbrücken. & . & . & - & ++ & + & + & - & - & - & - & - & - \\
\hline Gärtner . . & . & . & - & - & - & - & - & - & - & - & - & - \\
\hline Coli I. . . & . & . & - & $+t$ & + & $\mp$ & - & - & - & - & - & - \\
\hline Coli II . . & . & . & - & - & - & - & - & - & - & - & - & - \\
\hline Coli III . & & & - & $+\cdot$ & 一 & - & - & - & - & - & - & - \\
\hline Kruse . . & & . & - & - & - & - & - & - & - & - & - & - \\
\hline Faec. alcalig. & " & • & Ps. & Ps. & Ps. & Ps. & Ps. & Ps. & Ps. & Ps. & Ps. & Ps. \\
\hline Nietleben & & $\cdot \cdot$ & $1-$ & $\mp$ & - & - & - & - & - & - & - & - \\
\hline
\end{tabular}

Ein Blick auf Tabelle XXV bis XXVII lehrt uns, welche Irrthümer und Fehlerquellen aus der Anwendung zu schwacher Sera entstehen können. Wollte man nämlich die hiermit erhaltenen Resultate als beweisend betrachten, so könnte kaum ein Unterschied zwischen Typhus-, Coli- und typhusähnlichen Arten gefunden werden. Besonders deutlich zeigt sich in den Tabellen $\mathrm{XXV}$ und $\mathrm{XXVI}$, wie bei Anwendung eines unzulänglichen Serums die scharfen Grenzen der verschiedenen Arten verwischt werden und ein Serum von dem Titer 1:200 z. B. Typhus- und Paratyphusstämme ohne Unterschied in gleicher Stärke $(1: 100)$ agglutinirt. $\mathrm{Ja}$, in beiden Tabellen zeigt sogar eine Coli-Cultur (Coli I) eine noch weiter gehende Beeinflussung, als die dem specifischen Serum zugehörigen Stämme.

Gerade diese letztere Thatsache dürfte zur Stütze der von mir oben geäusserten Ansicht noch weiter an Bedeutung gewinnen, wenn man berücksichtigt, dass die hochwerthigen Sera der Culturen Strassburg B und Schottmüller B das Bacterium Coli I keineswegs höher, sondern im Gegentheil noch schwächer agglutinirten als die specifisch minderwerthigen Sera. 


\section{Schlussbemerkungen.}

Meine Versuche haben also gezeigt, dass die sieben Typhusculturen, welche zur Verfügung standen, ohne Unterschied und ohne Rücksicht auf Herkunft und Alter von jedem einzelnen Typhusserum gleich stark agglutinirt wurden. Die Paratyphus-, Coli-, sowie alle anderen typhus- oder coliähnlichen Bakterien wurden dagegen durch die verschiedenen Typhussera in weit schwächerer Weise beeinflusst. Die Agglutinationswirkung hielt sich diesen Arten gegenüber innerhalb enger, die echte Typhusagglutination nicht annähernd erreichender Grenzen.

Umgekehrt wirkten die mit diesen typhusähnlichen Arten gewonnenen Sera auf echte Typhusbacillen im Allgemeinen gar nicht, oder nur in unbedeutendem Maasse. Eine Ausnahme schienen lediglich die Sera ,Schottmüller A“, „Strassburg B“ und besonders „,Saarbrücken" zu bilden, insofern als dieselben auch Typhusculturen in ziemlich hohem Grade zu beeinflussen vermochten. Die Annahme, dass wir bei diesen Stämmen der Paratyphusgruppe kein. specifisch wirksames Immunserum zu gewinnen vermögen und die nahe Verwandtschaft zu einer "Mit"s oder „GruppenAgglutination" von echten Typhusbacillen führe, möchte ich trotzdem zunächst nur mit Vorsicht aussprechen. Einmal ist nämlich der Umstand zu berücksichtigen, dass, wie bereits erwähnt, die genannten Stämme umgekehrt durch Typhusserum keineswegs in ungewöhnlich starker Weise agglutinirt wurden, dann aber fand ich mich, auf Grund besonderer Versuche, vor allen Dingen zu der Vermuthung berechtigt, dass die dem Gesetze der Specifität anscheinend widersprechenden Befunde bei der Anwendung sehr hochwerthiger Sera verschwunden wären. Einen experimentellen Beweis für die Richtigkeit dieser Anschauung vermochte ich aus äusseren Gründen leider nicht zu erbringen. Dass eine solche Vermuthung jedoch in hohem Maasse berechtigt war, zeigten deutlich die mit einigen schwach wirksamen Serumproben gewonnenen Resultate. Wurden nämlich Sera, die nur deu Titer $1: 100$ bis $1: 200$ erreichten, zur Prüfung verwendet, so erschienen die Agglutinationsgrenzen bei den verschiedenen Typhus-, Paratyphus- und Coliarten derartig verwischt, dass eine klare Differenzirung überhaupt nicht mehr möglich war. Es ist daher, wie ich bestimmt glauben und auf Grund meiner obigen Versuche aussprechen möchte, zur entscheidenden Agglutinationsprobe die Benützung eines hochwerthigen Immunserums von dem Werthe 1:5000 bis 1:10000 unerlässliche Vorbedingung. 
Auf Grund der Agglutinationsprüfung konnte ich ferner eine Trennung der als "Paratyphus" bezeichneten Bacillen in $\mathrm{z}$ wei Typen bestätigen. Dem Typus B wurde auch der Bac. Saarbrücken angereiht.

Der Bac. faecalis alcaligenes, der Ruhrbacillus (Kruse) und der B. Nietleben bilden, wie aus den Untersuchungen hervorgeht, jeder eine besondere Art für sich.

Der Bac. enteritidis (Gärtner) wurde von Paratyphusseren fast gar nicht, von Typhusseren nur schwach agglutinirt; ausserdem übte das mit ihm gewonnene Serum in keinem Falle auf Typhus- oder Paratyphusbacillen eine stärkere Wirkung aus. Ich muss diesem Stamme daher entschieden eine selbstständige Stellung ausserhalb der Typhus-, Paratyphus- und auch Coliarten zusprechen, und befinde mich in dieser Hinsicht in völliger Uebereinstimmung mit den Angaben ron Bruns und Kayser, sowie Conradi, Drigalski und Jürgens. Das gelegentliche Vorkommen einer spontanen Agglutination bezw. Pseudoagglutination bei diesem Stamme erklärt es vielleicht; weshalb die Angaben gerade bezüglich der Agglutinirbarkeit des Bac. enteritidis durch Typhus- und typhusähnliche Sera zum Theil recht widersprechender Natur sind. (Vgl. z. B. Bonhoff).

Von den geprüften Coliculturen zeigten sich drei gegen Typhus-, Paratyphus- und andere Sera unempfindlich, nur ein Stamm, Coli I, wurde mitunter in etwas höherem Maasse von Typhus- und Paratyphusseren beeinflusst. Mit Ausnahme der Paratyphussera, deren unzureichende Agglutinationshöhe, wie bereits erwähnt, die relativ erhebliche Mitagglutination dieses Stammes wohl erklärlich macht, liessen indessen die übrigen Immunsera zwischen der Agglutinationsgrenze der gleichen Balterienarten und dem B. coli I eine immerhin sehr beträchtliche Kluft. Sehr bemerkenswerth erschien es, dass ebenso, wie nur der Stamm Coli I als einzige von den geprüften Coliculturen stärker durch andersartige Sera agglutinirt wurde, so auch das mit diesem Stamme dargestellte Im. munserum ganz allein nur auf die homologe Cultur, aber auf keine der übrigen Coliculturen wirkte. Da fernerhin das mit der Cultur Coli II gewonnene Serum gleichfalls strengste Specifität offenbarte, nur den homologen Stamm beeinflusste und die übrigen Coliarten (I, II, IV) unberührt liess, so dürften diese Beobachtungen entschieden dafür sprechen, dass wir bei der Prüfung und Identificirung von Colistämmen mit Hülfe der Agglutination eine gewisse Vorsicht walten lassen müssen. Ein Coli-Immunserum scheint eben nach meinen und anderweitigen Erfahrungen in der Regel nur für den gleichen Stamm, nicht für die ganze Art specifisch zu sein. 
Die Wirkungsweise eines mit Bac. coli III und IV hergestellten Serums zu prüfen, wie es im Interesse einer vollständigen wechselseitigen Controle eigentlich wünschenswerth gewesen wäre, scheiterte leider an der Unmöglichkeit ein Serum zu erlangen, dessen Werth über 1:50, höchstens 1:100 hinausging.

Alle diese Schlussfolgerungen stützen sich auf die Resultate, welche nach 20 bis 24 . Stunden gewonnen wurden. Es muss an dieser Stelle nochmals darauf hingewiesen werden, dass eine Betrachtung der Agglutinationsproben nach kürzerer Zeit sehr unzurerlässige Ergebnisse liefern und zu Fehldiagnosen führen kann. Es giebt nämlich leicht agglutinable Stämme, die sehr rasch und stark agglutinirt werden, und schwer agglutinable, bei denen ein positiver Ausfall der Agglutination erst später auftritt. Nach meinen Beobachtungen ist diese verschiedene Reactionsfähigkeit lediglich in der Art der Bakterien, nicht etwa in der Beschaffenheit und irgen'd welchen Besonderheiten des Serums zu suchen.

Die makroskopische Besichtigung der Röhrchen giebt, wie meine Beobachtungen bestätigt haben, im Allgemeinen klare und zuverlässige Ergebnisse. Sie gestattet im Besonderen bei einiger Uebung fast ebenso sicher wie die mikroskopische Untersuchung die Scheidung echter Agglutination von der Pseudoagglutination.

Eine so streng specifische Agglutinationswirkung, wie sie dem Serum der Cholera- und choleraähnlichen Vibrionen zukommt und daher jeder Zeit eine Identificirung bezw. Trennung dieser Bakterienarten in schärfster Weise gestattet, scheint für die Gruppe der Typhus-, Coli-, typhusähnlichen und coliähnlichen Stämme nicht allgemein in demselben ausgesprochenen Maasse zu bestehen. Wohl pflegt, wie die mitgetheilten Untersuchungen zeigen, mit Hülfe eines beliebigen hochwerthigen Typhusserums nur bei echten Typhusculturen ejne hochgradige Agglutination erhalten zu werden, doch treten umgekehrt bei Anwendung eines Paratyphusserums, eines Coliserums u. s. w. auch gegenüber nahe verwandten Arten mitunter Nebenwirkungen auf, welche in dieser Höhe bei der Agglutination von Cholera- und choleraähnlichen Bakterien wohl nur selten vorkommen dürften. Diese Thatsache ist gewiss von erheblichem biologischen Interesse. Ihre praktische Bedeutung braucht jedoch, wie ich glaube, weniger hoch veranschlagt zu werden. Denn schon wenn man es sich zum Grundsatze macht, bei der Bestimmung von Typhusoder typhusähnlichen Mikroorganismen stets auch das culturelle Verhalten des fraglichen Stammes nach allen Richtungen sorgfältig zu prüfen, so würde z. B. bei den von mir untersuchten Stämmen doch niemals ein Zweifel über den wahren Charakter der Cultur entstanden 
sein. Vor allen Dingen aber lässt sich bei der Agglutinationsprüfung die Gefahr einer Fehldiagnose in Folge von Mitagglutination andersartiger Bakterien auf ein Minimum reduciren, sobald man immer nur hochwerthige Sera von einem Agglutinationstiter $1: 2000$ bis $1: 10000$ als Testsera heranzieht. Wenigstens habe ich bei meinen Versuchen den Eindruck gewonnen und an verschiedenen Tabellen nachweisen können, dass mit dem Steigen der Agglutinationskraft eines Typhusserums für Typhusbacillen im Allgemeinen der Agglutinationstiter für die typhusähnlichen Arten der gleiche blieb wie bei einem schwächeren Serum. Auch in den meisten anderen Fällen schien, soweit ich dies feststellen konnte, ein Parallelismus zwischen der Höhe der specifischen Agglutination des homologen Stammes und der Nebenwirkung auf heterologe Stämme keineswegs die Regel zu sein. Unter allen Umständen wird man bei jeder Agglutinationsprüfung, die zu diagnostischen Zwecken ausgeführt wird, den erhaltenen Wirkungswerth nicht einfach als einen absoluten betrachten dürfen, sondern mit dem specifischen Titer des Serums für die homologe Cultur zu vergleichen haben.

Dem Hrn. Geh. Med. Rath Prof. Dr. C. Fraenkel spreche ich für die gütige Aufnahme in seinem Institut und dem Hrn. Prof. Dr. Sobernheim für die Anregung und Unterstützung bei dieser Arbeit meinen ergebensten Dank aus. 


\section{Litteratar-Verzeichniss.}

1. R. Pfeiffer, Weitere Untersuchungen über das Wesen der Choleraimmunität und über specifisch baktericide Processe. Diese Zeitschrift. 1894. Bd. XVIII. Die Differentialdiagnose der Vibrionen der Cholera asiatica mit Hülfe der Immunisirung. Ebenda. 1895. Bd. XIX.

2. Pfeiffer a. Kolle, Zur Differentialdiagnose der Typhusbacillen. Deutsche med. Wochenschrift. 1896.

3. Gruber, Theorie der activen und passiven Immunität gegen Cholera, Typhus und verwandte Krankheitsprocesse. Münchener med. Wochenschrift. 1896.

4. Pfeiffer, Kritische Bemerknngen zu Gruber's Theorie der activen und passiven Immunität. Deutsche med. Wochenschrift. 1896.

5. Van de Velde, Valeur de l'agglatination dans la sérodiagnose. Centralblatt für Bakteriologie. 1898. Bd. XXIII.

6. Stern, Typhusserum und Colibacillen. Ebenda. 1898. Bd. XXIII.

7. C. Mann, Beiträge zur Frage der specifischen Wirkung der Immunsera. Archiv für Hygiene. 1899. Bd. XXXIV

8. M. Jatta, Experimentelle Untersuchungen über die Agglutination des Typhusbacillus und der Mikroorganismen der Coligruppe. Diese Zeitschrift. 1900. Bd. XXXII.

9. Sternberg, Zur Verwerthbarkeit der Agglutination für die Diagnose der Typhusbacillen. Ebenda. 1900. Bd. XXXIV.

10. Roth berge r, Ueber Agglutination des Bact. coli. Ebenda. 1900. Bd. XXXIV.

11. Radziewsky, Beitrag zur Kenntniss des Bacterium coli. Ebenda. 1900.

12. A. Castellani, Ueber das Verbältniss der Agglutination za den Schutzkörpern. Ebenda. 1901. Bd. XXXVII.

13. Schottmüller, Ueber eine das Bild des Typhus bietende Krankheit, hervorgerufen durch typhusähnliche Bacillen. Deutsche med. Wochenschrift. 1900. Weitere Mittheilungen über mehrere das Bild des Typhus bietende Krankheitsfälle, hervorgerufen durch typhusähnliche Bacillen. Diese Zeitschrift. 1901.

14. Kurth, Ueber typhusähnliche, durch einen bisher nicht beschriebenen Bacillus bedingte Erkrankungen. Deutsche med. Wochenschrift. 1901.

15. A. Brion und H. Kayser, Ueber eine Erkrankung mit dem Befund eines typhusähnlichen Bacteriums im Blute. Münchener med. Wochenschrift. 1902.

16. H. Kayser, Ueber den Paratyphus. Deutsche med. Wochenschrift. 1903.

17. Conradi, v. Drigalski and Jürgens, Eine anter dem Bilde des Typhas verlaufende, durch einen besonderen Erreger bedingte Epidemie. Diese Zeitschrift. Bd. XLII.

18. Bruns and Kayser, Ueber die Verwerthbarkeit des Agglutinationsphänomens zur klinischen Diagnose and zur Identificirung ron Bakterien der TyphusColigruppe. Diese Zeitschrift. 1903. Bd. XLIII. 
19. Jürgens, Beobachtungen über die Widal'sche Reaction und die Mitagglutination der Typhusbacillen. Diese Zeitschrift. 1903. Bd. XLIII.

20. Zupnik und Posner. Typhus und Paratyphus. Prager med. Wochenschrift. 1903. Nr. 18.

21. W. Korte, Ein Beitrag zur Kenntniss des Paratyphus. Diese Zeitschrift. 1903. Bd. XLIV.

22. Hoffmann, Zur Frage des Paratyphus mit besonderer Berücksichtigung der bei ihm fehlenden Widal'schen Reaction. Hygienische Rundschau. 1902.

23. B. Lipschütz, Ueber die bakteriol. Diagnose des Typhos abdom. u. s. w. Centralblatt für Bakteriologie. 1904. Bd. XXXV.

24. Erne, Ein Fall von Paratyphus. Münchener med. Wochenschifif. 1904. Nr. 34.

25. Blumenthal, Ueber das Vorkommen von Typhus- und Paratyphusbacillen bei Erkrankungen der Gallenwege. Ebenda. 1904. Nr. 38.

26. H. Bonh off, Ueber die Identität des Löffler'schen Mäusetyphusbacillus mit dem Paratyphusbacillus des Typus B. Archiv für Hygiene. 1904. Bd. L.

27. F. Ballner und v. Sagasser, Ueber die Bildung ron homologen und heterologen Agglutinationen im Thierkörper. Ebenda. 1904. Bd. LI. 